\title{
The Role of Diet in the Prevention of Diabetes among Women with Prior Gestational Diabetes: A Systematic Review of Intervention and Observational Studies
}

Ellie D’Arcy, PhD, AdvAPD*; Jessica Rayner, APD*; Allison Hodge, PhD; Lynda J. Ross, PhD, AdvAPD*; Danielle A. J. M. Schoenaker, PhD

\author{
ARTICLE INFORMATION \\ Article history: \\ Submitted 5 February 2019 \\ Accepted 26 July 2019
}

Keywords:
Pregnancy
Diabetes
Nutrition
Intervention
Systematic review

Supplementary materials:

Tables 3, 4, and 7 and Figures 2, 4, and 5 are available at www.jandonline.org

2212-2672/Copyright (C) 2019 by the Academy of Nutrition and Dietetics.

https://doi.org/10.1016/j.jand.2019.07.021

*AdvAPD $=$ Advanced Accredited Practising Dietitian (certified in Australia).

${ }^{\ddagger} \mathrm{APD}=$ Accredited Practising Dietitian (certified in Australia).

\begin{abstract}
Background Women with prior gestational diabetes (GDM) have an increased lifetime risk of developing type 2 diabetes mellitus (T2DM). There are no up-to-date systematic reviews analyzing the relationship of diet with risk of developing T2DM following GDM. Objective To systematically review the evidence from intervention and observational studies on effects of dietary interventions and associations of dietary intake with T2DM outcomes in women with a GDM history.

Methods Six electronic databases were searched (Cumulative Index to Nursing and Allied Health Literature, Embase, Medline, Cochrane Central, Proquest, and Scopus) for articles published until May 2019. This review includes intervention and observational studies among women of any age with a history of GDM that reported on the effects of dietary interventions or association of dietary intake (energy, nutrients, foods, dietary patterns) with T2DM, impaired glucose tolerance, impaired fasting glucose, or prediabetes.
\end{abstract}

Results The systematic review identified five articles reporting results from four intervention studies, and seven articles reporting results from four observational studies. Findings from intervention studies indicated trends toward beneficial effects of a low-glycemic index diet, a low-carbohydrate diet, and a diet in line with general population dietary guidelines, but studies had unclear or high risk of bias. Findings from two cross-sectional and one prospective study indicated poorer diabetes outcomes for women with higher intakes of branched-chain amino acids, total and heme iron, and a diet relatively low in carbohydrates and high in animal fat and protein, and better outcomes among those consuming diets rich in fruit, vegetables, nuts, fish, and legumes, and low in red and processed meats and sugar-sweetened beverages, after adjustment for confounders, including body mass index.

Conclusions Findings from observational studies support current dietary guidelines for the prevention of T2DM. Further dietary intervention studies are needed to confirm whether or not dietary modification following a GDM pregnancy reduces women's risk of developing T2DM.

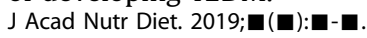

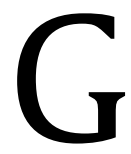

ESTATIONAL DIABETES MELLITUS (GDM) IS defined as "glucose intolerance that begins or is first diagnosed during pregnancy." ${ }^{1}$ Worldwide, the prevalence of GDM varies from an average of $6 \%$ in Europe to $13 \%$ in the Middle East and North Africa depending on factors such as health and lifestyle behaviors, ethnicity, and diagnostic criteria, ${ }^{2}$ and the incidence is increasing globally. ${ }^{3}$ GDM usually resolves during the postpartum period; however, women with a history of GDM remain a high-risk group for future development of type 2 diabetes mellitus (T2DM). Approximately $50 \%$ of women with a history of GDM will go on to develop T2DM within 5 to 19 years after delivery. ${ }^{2,4}$
T2DM causes numerous complications, including retinopathy, kidney failure, cardiovascular disease, and lower limb amputation that increase an individual's overall risk of dying prematurely. ${ }^{5}$ The burden of diabetes is enormous worldwide; for example, in 2017 diabetes was responsible for 4 million deaths and accounted for at least $\$ 727$ billion in health expenditure globally. ${ }^{6}$ Interventions that successfully prevent or delay the onset of T2DM in women with a previous history of GDM have the potential to improve an individual's long-term health and reduce the burden of morbidity associated with diabetes. ${ }^{7}$

Several systematic reviews and meta-analyses examining the effect of behavioral interventions, including increasing 
physical activity and/or improving diet quality, on diabetes risk in women with prior GDM have previously been published. $^{7-10}$ Two reviews that included meta-analyses highlighted that although intervention is generally superior to no intervention, effect estimates varied widely between intervention studies. ${ }^{8,10}$ One potential explanation for this heterogeneity in findings may be that results were pooled from diverse study types that examined the effects of interventions with goals related to diet modification alone, physical activity alone, and both diet modification and physical activity. ${ }^{8,10}$ In addition to intervention studies, one review included observational studies and found a limited number of studies that suggested healthful dietary patterns may be associated with lower risk of developing T2DM. ${ }^{7}$ These previous reviews included studies published until early 2016 (for intervention studies) ${ }^{10}$ or until 2014 (for observational studies). ${ }^{7}$ Further systematic reviews are therefore needed to provide an up-todate synthesis of the current evidence, incorporating findings from intervention and observational studies.

Interventions that focus on dietary modification alone may have the largest potential to improve diabetes outcomes in women with a history of GDM. For example, meta-analyses examining interventions aimed at reducing postpartum weight retention, which may positively influence diabetes risk, have found that physical activity-only interventions had no significant influence on postpartum weight loss, ${ }^{11}$ whereas diet-only interventions achieved significant weight loss. ${ }^{12}$ In practice, engagement and compliance with multicomponent interventions, particularly with advice to increase physical activity during the postpartum period and beyond, may be compromised due to barriers faced by women at this life stage. Barriers such as time constraints related to childcare and returning to work may reduce the effectiveness of interventions. ${ }^{13-15}$

There are currently no up-to-date systematic reviews or meta-analyses that have focused specifically on the effects of diet-only interventions or dietary intake on risk of developing diabetes among women with a previous history of GDM, and that incorporate evidence from both intervention and observational studies. Therefore, the aim of this research was to systematically review published intervention and observational studies to identify any effect of dietary interventions and associations of dietary intake with future diabetes risk for women with a previous diagnosis of GDM.

\section{MATERIALS AND METHODS}

The review was registered with PROSPERO International prospective register of systematic reviews (CRD42018090887) (http://www.crd.yorkac.uk/PROPSERO). Methods of the review were developed using the Cochrane Handbook for Systematic Reviews of Interventions ${ }^{16}$ and the Preferred Reporting Items for Systematic Reviews and Meta-Analyses guidelines were used for reporting the methods and outcomes. ${ }^{17}$

\section{Eligibility Criteria}

The review included dietary intervention (intervention trials, including counseling and/or food provided by any health professional) or dietary intake (observational) studies targeting women of any age, with a previous diagnosis of GDM. Because the focus of this review included the prevention of (pre-) diabetes in women with prior GDM, recruitment may

\section{RESEARCH SNAPSHOT}

Research Question: Does diet play a role in the prevention of diabetes among women with a history of gestational diabetes?

Key Findings: This systematic review identified 12 articles published until May 2019, including five articles reporting on findings from four intervention studies and seven articles reporting on findings from four observational studies.

Intervention studies generally indicated a trend toward beneficial effects of a low-glycemic index diet, a lowcarbohydrate diet, and a diet in line with general population guidelines, but had a high risk of bias.

Observational studies indicated poorer diabetes outcomes for women with higher intakes of branched chain aminoacids, total and heme iron, and a diet relatively low in carbohydrates and high in animal fat and protein, and better outcomes for women consuming diets rich in fruit, vegetables, nuts, fish, and legumes, and low in red and processed meats and sugar-sweetened beverages.

have commenced during pregnancy; however, studies were only included in the case that they reported outcomes and interventions during the postpartum period and beyond. Included interventions were those promoting a change in dietary intake, rather than nutritional supplement use, or other lifestyle behaviors (eg, physical activity). Supplementonly studies, including the provision of a capsule, pill, or tablet containing amino acids, vitamins, or minerals were excluded. Trials where multiple lifestyle interventions were combined, were included in the case that diet was reported as a separate intervention arm or effect. Dietary intake could be assessed as energy, nutrients, foods, dietary patterns, or fortified food products. Randomized controlled trials (RCTs); controlled trials; pre-post studies; as well as cross-sectional, retrospective, and prospective studies were included in the systematic review. When multiple publications were available for the same study, the publication reporting the greatest number of participants for each outcome was selected. Figure 1 highlights the population, intervention/ exposure, comparator, outcomes, study design categories for the formulation of the research question.

\section{Search Strategy}

The search strategy was developed in consultation with a subject specialist librarian. A systematic search for publications occurred in November 2017, and an updated search for any new publications in May 2019. The search was conducted without date limits, using six electronic databases: Cumulative Index to Nursing and Allied Health Literature, Embase, Medline, Cochrane Central, Proquest, and Scopus. The following medical subject heading terms, words and combinations of words were searched: "gestational diabetes" or GDM or "pregnancy diabetes mellitus" or "pregnancy induced diabetes"); and (history or "medical history" or previous*); and (diet* or food* or carbohydrate* or nutrition* or "glycemic index" or GI); and ("type 2 diabetes" or diabetes or DM or T2DM or "impaired glucose tolerance" or 


\begin{tabular}{|l|l|}
\hline Category & Result \\
\hline Population & $\begin{array}{c}\text { Women (postpartum onward) with a } \\
\text { history of gestational diabetes }\end{array}$ \\
\hline $\begin{array}{c}\text { Intervention/ } \\
\text { exposure }\end{array}$ & $\begin{array}{c}\text { Dietary intervention (intervention } \\
\text { studies), or dietary intake (energy, } \\
\text { nutrients, foods, or dietary patterns) } \\
\text { (observational studies) }\end{array}$ \\
\hline Comparison & $\begin{array}{c}\text { Control group (eg, standard care as part } \\
\text { of randomized controlled trial) or no } \\
\text { control group (eg, pre-post } \\
\text { intervention study), not applicable for } \\
\text { observational studies }\end{array}$ \\
\hline Outcome & $\begin{array}{c}\text { Type 2 diabetes, impaired glucose } \\
\text { tolerance, impaired fasting glucose, or } \\
\text { prediabetes }\end{array}$ \\
\hline Study & $\begin{array}{c}\text { Intervention studies (ie, no restrictions on } \\
\text { randomization and inclusion of a control } \\
\text { group), observational studies (ie, cross- } \\
\text { sectional, retrospective, and prospective } \\
\text { studies) }\end{array}$ \\
\hline
\end{tabular}

Figure 1. Categories for formulation of the research question for a systematic review on effects of dietary interventions and associations of dietary intake with diabetes outcomes in women with a history of gestational diabetes.

"prediabetes" or "impaired fasting glucose"). Keywords were searched as free text in the title, abstract, or topic and combined using the Boolean operator "AND." Limits included English language and human subjects. Details on the search strategy used for Embase are given in Figure 2 (available at www.jandonline.org). Other publications were identified from the reference lists of included articles and from relevant previously published review articles.

\section{Selection Process}

All records identified were assessed by two independent reviewers for eligibility based on the information contained in the title and abstract. The full text of all publications that appeared to meet the eligibility screening (Figure 1) was retrieved and subjected to a second independent assessment for relevance. Any discrepancy in assessment between reviewers was resolved through discussion.

\section{Quality Assessment}

Selected full text articles were assessed for methodologic quality by two independent reviewers. Intervention studies were assessed using the Cochrane risk of bias tool. ${ }^{16}$ All intervention studies were coded as low, high, or unclear risk in relation to sequence generation, allocation concealment, blinding of participants and personnel, blinding of outcome assessment, incomplete outcome data, and selective reporting. The Newcastle-Ottawa Scale was used to assess the quality of nonrandomized studies, including case-control and cohort studies. ${ }^{19} \mathrm{~A}$ star system is used to classify the studies as good, fair, or poor quality in relation to the selection of study groups, the comparability of groups and the ascertainment of either the exposure or outcome of interest for case-control and cohort studies, respectively. Any discrepancies were discussed between reviewers and resolved.

\section{Data Extraction}

Two independent reviewers extracted relevant data from all included articles. The extracts were compared, and any difference was verified and resolved through discussion. The following information was extracted for all studies: study design, country, recruitment setting, eligibility criteria, population characteristics, duration of follow-up (if applicable), outcomes examined, outcome assessment and diagnostic criteria, outcome incidence (for binary outcomes), results, and covariates included in analysis. For intervention studies, intervention groups, duration, goals, content, and compliance were extracted and for observational studies exposures examined and exposure assessment were extracted.

\section{Data Synthesis and Analysis}

Due to heterogeneity across studies in dietary factors, study design, and outcomes of interest, it was not possible to combine study findings in a meta-analysis. Instead, results indicating significance and direction of the observed associations were qualitatively summarized in tables for each study. Information on study characteristics was extracted to describe studies and populations.

\section{RESULTS}

The numbers of identified and included studies are shown in Figure 3. The database search $(n=1,201)$ and screening of bibliographies $(n=3)$ yielded 1,204 unique articles. After screening of titles and abstracts, 45 full-text articles were reviewed. Of these, 12 met the inclusion criteria. Multiple articles were published based on data from a Malaysian dietary intervention $(n=2)^{19,20}$ and the Nurses' Health Study II (NHSII) $(n=4) .{ }^{21-24}$ Therefore, this review includes five articles $^{19,20,25-27}$ reporting on findings from four intervention studies, and seven articles ${ }^{21-24,28-30}$ reporting on findings from four observational studies.

\section{Study Characteristics}

The main characteristics of the included intervention and observational studies are summarized in Tables 1 and 2. Detail on diabetes outcome assessment in each study, and on intervention goals, content, and compliance (intervention studies) and dietary assessment (observational studies) are described in Tables 3 and 4 (available at www.jandonline.org).

\section{Intervention Studies}

Intervention studies included RCTs conducted in Malaysia $(\mathrm{n}=65 \text { to } 77)^{19,20}$ and Australia $(\mathrm{n}=193),{ }^{26}$ and randomized crossover studies from the United States $(\mathrm{n}=17)^{25}$ and Sweden $(n=7)^{27}$ (Table 1 ). Women had a mean baseline age between 31 and 40 years, and mean baseline body mass index (BMI) between 25 and 28. The studies from Malaysia, the United States, and Sweden recruited high-risk women who were overweight or obese,,$^{19,20,25}$ had prediabetes or a family history of diabetes, ${ }^{19,20}$ or had a diagnosis of impaired glucose tolerance at 12 -months postpartum. ${ }^{27}$ Women were 


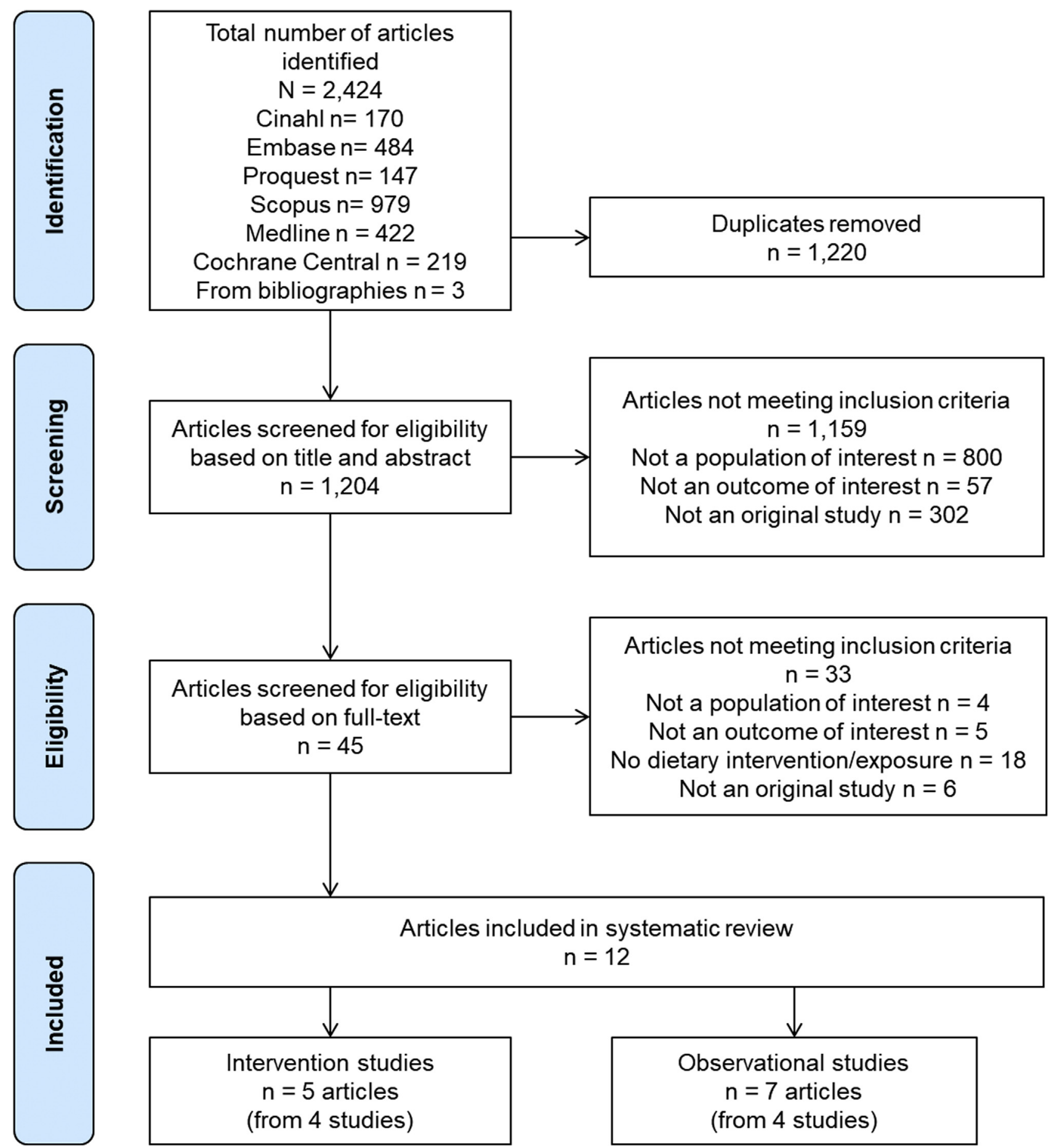

Figure 3. Flow diagram of the literature search and screening process for a systematic review on effects of dietary interventions and associations of dietary intake with diabetes outcomes in women with a history of gestational diabetes.

recruited at a median of 4 months post-GDM pregnancy in the Malaysian RCT ${ }^{19,20}$ and 1 to 3 years post-GDM in the Swedish crossover trial, ${ }^{27}$ whereas the time since GDM pregnancy was not reported in the studies from Australia or the United States. ${ }^{25,26}$

The dietary intervention studies focused on carbohydrate quality (glycemic index) $)^{19,20,27}$ and carbohydrate quantity (percentage of total energy intake), ${ }^{25}$ or included general advice in line with dietary guidelines ${ }^{26}$ (Table 3 , available at www.jandonline.org). The Malaysian low-glycemic index $\mathrm{RCT}^{19,20}$ included education sessions on restricting energy and fat intake and increasing dietary fiber intake, with the goal to achieve a $5 \%$ to $7 \%$ reduction in body weight (for women with BMI $>23$ ) or to maintain current weight (BMI 
Table 1. Characteristics of intervention studies included in a systematic review on effects of dietary interventions on diabetes outcomes in women with a history of gestational diabetes

\begin{tabular}{|c|c|c|c|c|c|c|c|}
\hline Author(s), year & Country & $\begin{array}{l}\text { Study design, } \\
\text { no. of women }\end{array}$ & Eligibility criteria & $\begin{array}{l}\text { Recruitment } \\
\text { setting }\end{array}$ & $\begin{array}{l}\text { Participant } \\
\text { characteristics }^{\text {a }}\end{array}$ & $\begin{array}{l}\text { Intervention groups, } \\
\text { duration, and follow-up }\end{array}$ & Outcome \\
\hline $\begin{array}{l}\text { Ghani and } \\
\text { colleagues, }^{19} \\
2014\end{array}$ & Malaysia & $\begin{array}{l}\text { Randomized } \\
\text { controlled } \\
\text { trial } \\
\mathrm{N}=77 \text { ( } \mathrm{n}=39 \text { in } \\
\text { low glycemic } \\
\text { index } \\
\text { intervention; } \\
\mathrm{n}=38 \text { in } \\
\text { control } \\
\text { group) }\end{array}$ & $\begin{array}{l}\text { Included: Women with a history of } \\
\text { gestational diabetes aged } 20-40 \\
\text { y, without a current diagnosis of } \\
\text { diabetes, at risk of type } 2 \\
\text { diabetes (at least } 1 \text { of the } 4 \\
\text { following risk factors: BMI }>23 \text {, } \\
\text { or waist circumference }>80 \mathrm{~cm} \text {, } \\
\text { or impaired glucose tolerance or } \\
\text { impaired fasting glucose, or a } \\
\text { family history of type } 2 \text { diabetes). } \\
\text { Excluded: Women with a diagnosis } \\
\text { of type } 2 \text { diabetes or presence of } \\
\text { other health complications and } \\
\text { use of drugs affecting body } \\
\text { weight and glucose control }\end{array}$ & $\begin{array}{l}\text { Women were } \\
\text { recruited } \\
\text { from the } \\
\text { endocrine } \\
\text { clinic of a } \\
\text { tertiary } \\
\text { hospital }\end{array}$ & $\begin{array}{l}\text { Time since } \\
\text { gestational } \\
\text { diabetes } \\
\text { pregnancy: } \\
\text { median } 4 \text { mo } \\
\text { Age at baseline } \\
\text { (mean): } 31 \text { y } \\
\text { Previous births } \\
\text { (mean): } 2 \\
\text { BMl }^{\text {b (mean): } 26}\end{array}$ & $\begin{array}{l}\text { (1) Low glycemic index } \\
\text { intervention } \\
\text { (2) Control group } \\
\text { Intervention duration not } \\
\text { reported. } \\
\text { Women were followed for } \\
12 \text { mo post-intervention }\end{array}$ & $\begin{array}{l}\text { Fasting plasma } \\
\text { glucose }\end{array}$ \\
\hline $\begin{array}{l}\text { Shyam and } \\
\text { colleagues, } \\
2013\end{array}$ & Malaysia & $\begin{array}{l}\text { Randomized } \\
\text { controlled } \\
\text { trial } \\
\mathrm{N}=65 \text { women } \\
\text { ( } \mathrm{n}=34 \text { in low } \\
\text { glycemic } \\
\text { index } \\
\text { intervention; } \\
\mathrm{n}=31 \text { in the } \\
\text { control } \\
\text { group) }\end{array}$ & $\begin{array}{l}\text { Included: Women with a history of } \\
\text { gestational diabetes aged } 20-40 \\
\text { y, without a current diagnosis of } \\
\text { diabetes, at risk of type } 2 \\
\text { diabetes (at least } 1 \text { of the } 4 \\
\text { following risk factors: BMI }>23 \text {, } \\
\text { or waist circumference }>80 \mathrm{~cm} \text {, } \\
\text { or impaired glucose tolerance or } \\
\text { impaired fasting glucose, or a } \\
\text { family history of type } 2 \text { diabetes). } \\
\text { Excluded: Women with a diagnosis } \\
\text { of type } 2 \text { diabetes or presence of } \\
\text { other health complications and } \\
\text { use of drugs affecting body } \\
\text { weight and glucose control }\end{array}$ & $\begin{array}{l}\text { Women were } \\
\text { recruited } \\
\text { from the } \\
\text { endocrine } \\
\text { clinic of a } \\
\text { tertiary } \\
\text { hospital }\end{array}$ & $\begin{array}{l}\text { Time since } \\
\text { gestational } \\
\text { diabetes } \\
\text { pregnancy: } \\
\text { median } 4 \text { mo } \\
\text { Age at baseline } \\
\text { (mean): } 31 \text { y } \\
\text { Previous births } \\
\text { (mean): } 2 \\
\text { BMI (mean): } 26\end{array}$ & $\begin{array}{l}\text { (1) Low glycemic index } \\
\text { intervention } \\
\text { (2) Control group } \\
\text { Intervention duration not } \\
\text { reported. } \\
\text { Women were followed for } 6 \\
\text { mo post-intervention }\end{array}$ & $\begin{array}{l}\text { Fasting plasma } \\
\text { glucose, 2-h } \\
\text { glucose }\end{array}$ \\
\hline
\end{tabular}


Table 1. Characteristics of intervention studies included in a systematic review on effects of dietary interventions on diabetes outcomes in women with a history of gestational diabetes (continued)

\begin{tabular}{|c|c|c|c|c|c|c|c|}
\hline Author(s), year & Country & $\begin{array}{l}\text { Study design, } \\
\text { no. of women }\end{array}$ & Eligibility criteria & $\begin{array}{l}\text { Recruitment } \\
\text { setting }\end{array}$ & $\begin{array}{l}\text { Participant } \\
\text { characteristics }^{\text {a }}\end{array}$ & $\begin{array}{l}\text { Intervention groups, } \\
\text { duration, and follow-up }\end{array}$ & Outcome \\
\hline $\begin{array}{l}\text { Östman and } \\
\text { colleagues, } \\
2006\end{array}$ & Sweden & $\begin{array}{l}\text { Randomized } \\
\text { crossover } \\
\text { study } \\
\mathrm{N}=7\end{array}$ & $\begin{array}{l}\text { Included: Women with a history of } \\
\text { gestational diabetes } 1-3 \text { y before } \\
\text { the study who had a diagnosis of } \\
\text { impaired glucose tolerance at } 12 \\
\text { mo postpartum }\end{array}$ & Not reported & $\begin{array}{l}\text { Age at baseline } \\
\text { (mean): } 32 \text { y } \\
\text { BMI (mean): } 28\end{array}$ & $\begin{array}{l}\text { (1) Dietary intervention } 1 \text { (2) } \\
\text { Dietary intervention } 2 . \\
\text { Participants were crossed } \\
\text { over after a 3-wk } \\
\text { intervention and 3-wk } \\
\text { washout period (total } \\
\text { duration } 9 \text { wk). } \\
\text { No control group. } \\
\text { No post-intervention } \\
\text { follow-up. }\end{array}$ & $\begin{array}{l}\text { Insulin } \\
\text { secretion, } \\
\text { insulin } \\
\text { sensitivity, } \\
\text { fasting } \\
\text { glucose, and } \\
\text { insulin }\end{array}$ \\
\hline $\begin{array}{l}\text { Wein and } \\
\text { colleagues, } \\
1999\end{array}$ & Australia & $\begin{array}{l}\text { Randomized } \\
\text { controlled } \\
\text { trial } \\
\mathrm{N}=193 \text { ( } \mathrm{n}=97 \\
\text { in } \\
\text { intervention } \\
\text { group; } \mathrm{n}=96 \\
\text { in control } \\
\text { group) }\end{array}$ & $\begin{array}{l}\text { Included: Women with a history of } \\
\text { gestational diabetes who had a } \\
\text { diagnosis of impaired glucose } \\
\text { tolerance and who could } \\
\text { communicate directly or } \\
\text { through translation. No } \\
\text { exclusion criteria reported }\end{array}$ & $\begin{array}{l}\text { Women were } \\
\text { recruited } \\
\text { from the } \\
\text { Mercy } \\
\text { Hospital for } \\
\text { Women in } \\
\text { Melbourne } \\
\text { between } \\
\text { November } \\
1989 \text { and July } \\
1991\end{array}$ & $\begin{array}{l}\text { Age at baseline } \\
\text { (mean): } 38-40 \text { y } \\
\text { Previous births } \\
\text { (mean): } 3 \\
\text { BMI (mean): } \\
25-26\end{array}$ & $\begin{array}{l}\text { (1) Lifestyle intervention } \\
\text { (2) Control group } \\
\text { Intervention duration not } \\
\text { reported. } \\
\text { Women were followed for } \\
\text { up to } 6 \text { y (median follow- } \\
\text { up }=51 \text { mo [ } 4 \text { y } 3 \text { mo] } \\
\text { post-intervention }\end{array}$ & Type 2 diabetes \\
\hline $\begin{array}{l}\text { Peterson and } \\
\text { colleagues, }^{25} \\
1995\end{array}$ & $\begin{array}{l}\text { United } \\
\text { States }\end{array}$ & $\begin{array}{l}\text { Randomized } \\
\text { crossover } \\
\text { study } \\
\mathrm{N}=17\end{array}$ & $\begin{array}{l}\text { Included: Women with a history of } \\
\text { gestational diabetes who were } \\
\text { overweight or obese, 1-4 y } \\
\text { postpartum, not nursing, and } \\
\text { aged } 21-50 \text { y } \\
\text { Excluded: Women with any } \\
\text { medical condition for which a } \\
\text { calorie-restricted diet may be } \\
\text { harmful, including pregnancy or } \\
\text { planned pregnancy during the } \\
\text { trial, hypertension, diuretics use, } \\
\text { thyroid disease, or diabetes }\end{array}$ & Not reported & $\begin{array}{l}\text { Age at baseline } \\
\text { (mean): } 34-38 \text { y } \\
\text { Previous births } \\
\text { (mean): } 3 \\
\text { BMI (mean): } \\
25-26\end{array}$ & $\begin{array}{l}\text { (1) Dietary intervention } 1 \text { (2) } \\
\text { Dietary intervention } 2 \\
\text { Participants were crossed } \\
\text { over after a 6-wk } \\
\text { intervention (total } \\
\text { duration=12 wk). } \\
\text { No control group. } \\
\text { No post-intervention } \\
\text { follow-up }\end{array}$ & $\begin{array}{l}\text { Serum fasting } \\
\text { insulin }\end{array}$ \\
\hline
\end{tabular}


Table 2. Characteristics of observational studies included in a systematic review on associations of dietary intake with diabetes outcomes in women with a history of gestational diabetes

Study design,

follow-up, no. of

Author(s), year Country women Eligibility criteria

Tobias and United Prospective nested Included: Women with colleagues, $^{24}$ States case- control prevalent gestational 2018

study (Nurses' Health Study II,

as part of the

Diabetes and

Women's Health

Study)

$\mathrm{N}=172$ diabetes

cases and 175

age-matched

controls

\begin{tabular}{|c|c|c|}
\hline $\begin{array}{l}\text { Mercier and } \\
\text { colleagues, }\end{array}$ & Canada & $\begin{array}{l}\text { Cross-sectional } \\
\text { No follow-up } \\
N=281\end{array}$ \\
\hline
\end{tabular}

Andersson-Hall Sweden Cross-sectional

\begin{tabular}{|c|c|}
\hline $\begin{array}{l}\text { and } \\
\text { colleagues, }{ }^{30}\end{array}$ & $\begin{array}{l}\text { No follow-up } \\
N=137\end{array}$ \\
\hline
\end{tabular}

2018

$\mathrm{N}=137$ diabetes before 1991, or

incident gestational

diabetes between 1991

and 2001, and with a

plasma sample available

from the biospecimen

collection

Excluded: Women with

cancer, missing dietary

data, or missing

metabolite data

Included: Women aged $\geq 18$ Women were recruited $y$ with a diagnosis of gestational diabetes

between 2003 and 2013.

Excluded: Women pregnant during the study or with diabetes before pregnancy

Included: Women diagnosed with gestational diabetes between 2005 and 2009

Connecticut, Indiana,

lowa, Kentucky,

Massachusetts,

Michigan, Missouri,

New York, North

Carolina, Ohio,

Pennsylvania, South

Carolina, and Texas

invitations

since 2009 through a

provincial health plan

registry and through

major hospitals within

a neonatal care unit in

Quebec City

through a telephone
In 1989, nurses aged

25-42 y in California,

were recruited through $\mathrm{BMI}^{\mathrm{b}}$ (mean): 31.6

medical records from 2

Years since first

gestational diabetes

pregnancy (mean):

12 y (cases) and 3 y

(controls)

Age at baseline blood

draw (mean): 43 y

Ethnicity: 91\% (cases)

94\% (controls)

white

(cases) and 25.5

(controls)

Time since gestational Fruit and diabetes pregnancy vegetable intake (mean): $6 \mathrm{y}$

Age at baseline

(mean): $37 \mathrm{y}$

Previous births

(mean): 2

BMI (mean): 26-29

Women were recruited in $\mathrm{Tim}$

interview

of branched-

chain amino

acids: isoleucine,

leucine and

valine

Time since gestational Intake of energy,

diabetes pregnancy

(mean): 6 y

Age at baseline characteristics $^{\mathrm{a}}$

Exposure(s) Outcome(s)

Total and subtypes Type 2 diabetes (mean): 38-41 y

Ethnicity: 33\%-53\%

Scandinavian

BMI (mean): 26-30
Abnormal glucose

tolerance,

including

impaired fasting

glucose, impaired

glucose tolerance,

prediabetes, and

type 2 diabetes

Impaired glucose

tolerance and

type 2 diabetes carbohydrates,

protein, and fat;

frequency of

meat, fish, and

vegetarian

meals; and type

of cooking fat

used (proportion

of butter,

margarine, and

vegetable oil) 
Table 2. Characteristics of observational studies included in a systematic review on associations of dietary intake with diabetes outcomes in women with a history of gestational diabetes (continued)

Study design,

follow-up, no. of

Author(s), year Country women Eligibility criteria

Participant

Bao and United Prospective cohort Included: Women with colleagues, $^{21} \quad$ States (Nurses' Health prevalent gestational 2016 Study II, as part of the Diabetes and Women's Health Study) diabetes before 1991, or incident gestational diabetes between 1991 and 2001.

Followed-up from Excluded: Women with 1991 to 2001, at chronic disease (type 2 4-yearly intervals diabetes, cardiovascular $\mathrm{N}=3,976$ disease, or cancer) before gestational diabetes pregnancy or before return of first postgestational diabetes food frequency questionnaire, multiple pregnancy, no postgestational diabetes food frequency questionnaire

Bao and United Prospective cohort Included: Women with colleagues, $^{22}$ States (Nurses' Health prevalent gestational 2016 Study II, as part of the Diabetes and Women's diabetes before 1991, or incident gestational diabetes between 1991 Health Study) and 2001.

Followed-up from Excluded: Women with 1991 to 2001, at chronic disease (type 2 4-yearly intervals diabetes, cardiovascular $\mathrm{N}=4,502$ disease, or cancer) before gestational diabetes pregnancy or before return of first postgestational diabetes

In 1989, nurses aged 25-42 y in California, Connecticut, Indiana, lowa, Kentucky, Massachusetts, Michigan, Missouri, New York, North Carolina, Ohio, Pennsylvania, South Carolina, and Texas were recruited through invitations

characteristics $^{\mathrm{a}}$

Exposure(s) $\quad$ Outcome(s)
Dietary total
iron, heme iron,
nonheme iron,
and
supplemental
iron (from
multivitamin
and specific iron
supplements)

Age at baseline (mean): 38 y

Ethnicity: 91\%-93\% white

$>1$ previous birth: 80\%-84\%

BMI (mean): 25-29
Overall (based on total

carbohydrate, protein, and fat intake), animal (based on total carbohydrate, animal protein and animal fat intake) and vegetable lowcarbohydrate dietary pattern (based on tota
Type 2 diabetes 
Table 2. Characteristics of observational studies included in a systematic review on associations of dietary intake with diabetes outcomes in women with a history of gestational diabetes (continued)

\begin{tabular}{|c|c|c|c|c|c|c|c|}
\hline Author(s), year & Country & $\begin{array}{l}\text { Study design, } \\
\text { follow-up, no. of } \\
\text { women }\end{array}$ & Eligibility criteria & Recruitment setting & $\begin{array}{l}\text { Participant } \\
\text { characteristics }^{\text {a }}\end{array}$ & Exposure(s) & Outcome(s) \\
\hline \multirow{3}{*}{$\begin{array}{l}\text { Tobias and } \\
\text { colleagues, }^{23} \\
2012\end{array}$} & & & $\begin{array}{l}\text { food frequency } \\
\text { questionnaire, multiple } \\
\text { pregnancy, no } \\
\text { postgestational diabetes } \\
\text { food frequency } \\
\text { questionnaire }\end{array}$ & & & $\begin{array}{l}\text { carbohydrate, } \\
\text { vegetable } \\
\text { protein, and } \\
\text { vegetable fat) }\end{array}$ & \\
\hline & $\begin{array}{l}\text { United } \\
\text { States }\end{array}$ & $\begin{array}{l}\text { Prospective cohort } \\
\text { (Nurses' Health } \\
\text { Study II, as part } \\
\text { of the Diabetes } \\
\text { and Women's } \\
\text { Health Study) } \\
\text { Followed-up from } \\
1991 \text { to 2001, at } \\
\text { 4-yearly intervals } \\
\mathrm{N}=4,413\end{array}$ & $\begin{array}{l}\text { Included: Women with } \\
\text { prevalent gestational } \\
\text { diabetes before 1991, or } \\
\text { incident gestational } \\
\text { diabetes between } 1991 \\
\text { and } 2001 \text {. } \\
\text { Excluded: Women with } \\
\text { chronic disease (type } 2 \\
\text { diabetes, cardiovascular } \\
\text { disease, or cancer) before } \\
\text { gestational diabetes } \\
\text { pregnancy or before return } \\
\text { of first postgestational } \\
\text { diabetes food frequency } \\
\text { questionnaire, multiple } \\
\text { pregnancy, no } \\
\text { postgestational diabetes } \\
\text { food frequency } \\
\text { questionnaire }>70 \text { food } \\
\text { frequency questionnaire } \\
\text { items left blank or } \\
\text { unrealistic energy intake } \\
\text { (<500 kcal/d or }>3,500 \\
\text { kcal/d) }\end{array}$ & $\begin{array}{l}\text { In 1989, nurses aged } \\
\text { 25-42 y in California, } \\
\text { Connecticut, Indiana, } \\
\text { lowa, Kentucky, } \\
\text { Massachusetts, } \\
\text { Michigan, Missouri, } \\
\text { New York, North } \\
\text { Carolina, Ohio, } \\
\text { Pennsylvania, South } \\
\text { Carolina, and Texas } \\
\text { were recruited through } \\
\text { invitations }\end{array}$ & $\begin{array}{l}\text { Time from gestational } \\
\text { diabetes pregnancy } \\
\text { to type } 2 \text { diabetes } \\
\text { diagnosis (mean): } \\
13.8 \text { y } \\
\text { Age at baseline } \\
\text { (mean): } 38 \text { y } \\
\text { Ethnicity: } 91 \%-93 \% \\
\text { white } \\
\text { BMI (mean): } 21-22\end{array}$ & $\begin{array}{l}\text { Three a priori } \\
\text { dietary pattern } \\
\text { scores: the } \\
\text { alternate } \\
\text { Mediterranean } \\
\text { diet, Dietary } \\
\text { Approaches to } \\
\text { Stop } \\
\text { Hypertension, } \\
\text { and alternate } \\
\text { Healthy Eating } \\
\text { Index }\end{array}$ & Type 2 diabetes \\
\hline & Korea & & $\begin{array}{l}\text { Included: Women with a } \\
\text { recent gestational }\end{array}$ & $\begin{array}{l}\text { Between June } 2006 \text { and } \\
\text { March 2009, pregnant }\end{array}$ & $\begin{array}{l}\text { Time since gestational } \\
\text { diabetes }\end{array}$ & $\begin{array}{l}\text { Total energy, } \\
\text { carbohydrates, }\end{array}$ & $\begin{array}{l}\text { Type } 2 \text { diabetes } \\
\text { and prediabetes }\end{array}$ \\
\hline
\end{tabular}


$<23)$. In the Swedish crossover trial, participants were provided with low-glycemic and high-fiber bread products or high-glycemic and low-fiber bread products, with the aim to determine effects on metabolic parameters. ${ }^{27}$ The dietary intervention that focussed on carbohydrate quantity was a crossover trial and included an energy-restricted diet where women received nutritional supplement bars that were identically wrapped and contained $20 \%$ protein and either $40 \%$ or $55 \%$ carbohydrates (ie, $40 \%$ or $25 \%$ of energy from fat, respectively) for breakfast, lunch, and snacks, and a meal plan for dinner that comprised one-third of total calories. The goal was to achieve weight loss of 1 to $2 \mathrm{lb}(0.45$ to $0.9 \mathrm{~kg})$ per week. ${ }^{25}$ The RCT conducted by Wein and colleagues ${ }^{26}$ included provision of a dietary advice sheet (Target on Healthy Eating) for intervention and control groups, whereas the intervention group in addition received telephone contact with a dietitian every 3 months (so possibly 24 times over a 6- year follow-up). Interventions were delivered through a combination of one-on-one sessions with nutritionists, group education sessions, e-mail, and short messaging reminders. ${ }^{19,20,25,26}$ Women in the control groups received general dietary recommendations and did not receive counseling or personal advice. All interventions were focused on dietary modifications and did not include specific advice or goals related to physical activity. In line with general physical activity recommendations, women in the intervention and control groups were encouraged to engage in moderate physical activity for 30 minutes at least five times a week ${ }^{19,20}$ or received a reminder of the need for regular exercise. ${ }^{26}$ Diabetes-related outcomes following the interventions included fasting plasma glucose, ${ }^{19,20,27}$ serum fasting insulin, ${ }^{25,27}$ insulin secretion and sensitivity, ${ }^{27}$ and T2DM defined using the 1985 World Health Organization guidelines ${ }^{26}$ (Table 3 , available at www. jandonline.org).

\section{Observational Studies}

Observational studies included cross-sectional studies from Canada $(\mathrm{N}=281),{ }^{29}$ Korea $(\mathrm{N}=381),{ }^{28}$ and Sweden $(\mathrm{N}=137),{ }^{30}$ a longitudinal study from the United States (NHSII $[\mathrm{N}=3,976$ to 4,502$),{ }^{21-23}$ and a nested case-control study within the NHSII $(\mathrm{n}=347)^{25}$ (Table 2). Women had a mean baseline age between 34 and 43 years, and a mean baseline BMI between 21 and 32. Studies were conducted at different times after GDM pregnancies, ranging from 6 to 12 weeks $^{28}$ to 14 years post-GDM pregnancy. ${ }^{23}$

Dietary intake was assessed using validated food frequency questionnaires ${ }^{21-24,29,30}$ or a 24 -hour dietary recall ${ }^{29}$ (Table 4 , available www.jandoline.org). Studies examined overall dietary patterns (low-carbohydrate dietary pattern ${ }^{22}$; alternate Mediterranean diet (aMED); Dietary Approaches to Stop Hypertension (DASH) and alternate Healthy Eating Index $(\mathrm{aHEI})^{23}$; fruit and vegetable intake ${ }^{29}$; frequency of meat, fish, and vegetarian meals ${ }^{30}$; cooking fat used $^{30}$; macronutrients $^{28,30}$; branched chain amino acidss ${ }^{24}$; and iron intake ${ }^{21}$ ). Diabetes-related outcomes, including abnormal glucose tolerance, prediabetes, and T2DM, were defined according to the 2017 American Diabetes Association Guidelines, ${ }^{21-24,28}$ the 2013 Canadian Diabetes Association Guidelines ${ }^{29}$ or the 1999 World Health Organization Guidelines ${ }^{30}$ (Table 4, available at www.jandoline.org). 
Table 5. Results from intervention studies included in a systematic review on effects of dietary interventions on diabetes outcomes in women with a history of gestational diabetes

Covariates

included in

\begin{tabular}{ll} 
Author(s), year & Outcome incid \\
\hline $\begin{array}{c}\text { Ghani and } \\
\text { colleagues, }\end{array}$ & $\begin{array}{c}\text { Not applicable } \\
\text { (continuous }\end{array}$ \\
2014 & outcome)
\end{tabular}

$\begin{array}{lc}\begin{array}{l}\text { Shyam and } \\ \text { colleagues, }^{20}\end{array} & \begin{array}{c}\text { Not applicable } \\ \text { (continuous }\end{array} \\ 2013 & \text { outcome) }\end{array}$

Results analysis

Changes in fasting plasma glucose (mean \pm standard deviation):

Women with fasting insulin $<2 \mu \mathrm{IU} / \mathrm{mL}^{\mathrm{a}}$ :

- Intervention group: $0.48 \pm 1.2 \mathrm{mmol} / \mathrm{L}^{\mathrm{b}}$

- Control group: $0.18 \pm 0.32 \mathrm{mmol} / \mathrm{L}^{\mathrm{b}} \quad(P=0.16$ for intervention vs control)

Women with fasting insulin $\geq 2 \mu \mathrm{lU} / \mathrm{mL}^{\mathrm{a}}$ :

- Intervention group: $-0.12 \pm 0.27 \mathrm{mmol} / \mathrm{L}^{\mathrm{b}}$

- Control group: $0.17 \pm 0.32 \mathrm{mmol} / \mathrm{L}^{\mathrm{b}}(P=0.03$ for intervention vs control)

Overall:

Changes in fasting plasma glucose (mean \pm standard deviation):
None/not reported

- Intervention group: $-0.2 \pm 0.6 \mathrm{mmol} / \mathrm{L}^{\mathrm{b}}$

- Control group: $0.1 \pm 0.6 \mathrm{mmol} / \mathrm{L}^{\mathrm{b}} \quad(P \geq 0.05$ for intervention vs control)

Changes in 2-h plasma glucose:

- Intervention group: $-0.2 \pm 2.8 \mathrm{mmol} / \mathrm{L}^{\mathrm{b}}$

- Control group: $0.8 \pm 2.0 \mathrm{mmol} / \mathrm{L}^{\mathrm{b}} \quad(P=0.03$ for intervention vs control)

Women with baseline normoglycemia:

Changes in fasting plasma glucose (mean \pm standard

deviation):

- Intervention group: $0.31 \pm 0.53 \mathrm{mmol} / \mathrm{L}^{\mathrm{b}}$

- Control group: $0.15 \pm 0.41 \mathrm{mmol} / \mathrm{L}^{\mathrm{b}} \quad(P=0.29$ for intervention vs control)

Changes in 2-h plasma glucose (mean \pm standard deviation):

- Intervention group: $0.24 \pm 2.04 \mathrm{mmol} / \mathrm{L}^{\mathrm{b}}$

- Control group: $0.88 \pm 1.2 \mathrm{mmol} / \mathrm{L}^{\mathrm{b}} \quad(P=0.22$ for intervention vs control)

Women with baseline dysglycemia:

Changes in fasting plasma glucose (mean \pm standard

deviation):

- Intervention group: $0.49 \pm 1.7 \mathrm{mmol} / \mathrm{L}^{\mathrm{b}}$

- Control group: $0.04 \pm 0.45 \mathrm{mmol} / \mathrm{L}^{\mathrm{b}} \quad(P=0.51$ for intervention vs control)

Changes in 2-h plasma glucose (mean \pm standard deviation):

- Intervention group: $-0.49 \pm 4.05 \mathrm{mmol} / \mathrm{L}$

- Control group: $0.47 \pm 2.22 \mathrm{mmol} / \mathrm{L}(P=0.57$ for intervention vs control)
Glycemic load and carbohydrate intake

(continued on next page) 
Table 5. Results from intervention studies included in a systematic review on effects of dietary interventions on diabetes outcomes in women with a history of gestational diabetes (continued)

\begin{tabular}{|c|c|c|c|}
\hline Author(s), year & Outcome incidence & Results & $\begin{array}{l}\text { Covariates } \\
\text { included in } \\
\text { analysis } \\
\end{array}$ \\
\hline $\begin{array}{l}\text { Östman and } \\
\text { colleagues, } \\
2006\end{array}$ & $\begin{array}{c}\text { Not applicable } \\
\text { (continuous } \\
\text { outcomes) }\end{array}$ & $\begin{array}{l}\text { No changes in fasting glucose, fasting insulin, and insulin } \\
\text { sensitivity after either intervention } \\
\text { No changes in insulin secretion after high glycemic index } \\
\text { and low-fiber bread products } \\
\text { Changes in insulin secretion after low glycemic index and } \\
\text { high fiber bread products: } 1,185.4 \pm 264 \mu \mathrm{lU} / \mathrm{mL}^{a} \text { min } \\
\text { (preintervention) to } 751.4 \pm 141 \mu \mathrm{lU} / \mathrm{mL}^{\mathrm{a}} \mathrm{min} \\
\text { (postintervention) at } 0-60 \mathrm{~min}(P<0.05)\end{array}$ & None/not reported \\
\hline $\begin{array}{l}\text { Wein and } \\
\text { colleagues, } \\
1999\end{array}$ & $\begin{array}{l}\text { Type } 2 \text { diabetes } \\
\text { incidence: } 26.8 \% \text { in } \\
\text { intervention group } \\
\text { and } 28.1 \% \text { in } \\
\text { control group }\end{array}$ & $\begin{array}{l}\text { Type } 2 \text { diabetes: Relative risk for intervention vs control } \\
\text { group: } 0.63(95 \% \mathrm{Cl} 0.35-1.14)\end{array}$ & $\begin{array}{l}\text { Intervention } \\
\text { group, entry age, } \\
\text { entry body mass } \\
\text { index and } \\
\text { change in body } \\
\text { mass index }\end{array}$ \\
\hline $\begin{array}{l}\text { Peterson and } \\
\text { colleagues, }^{25} \\
1995\end{array}$ & $\begin{array}{c}\text { Not applicable } \\
\text { (continuous } \\
\text { outcome) }\end{array}$ & $\begin{array}{l}\text { Serum fasting insulin at baseline, end of first intervention, } \\
\text { and end of second intervention, respectively } \\
\text { (mean } \pm \text { standard deviation): } \\
\text { - } 40 \% \text { Carbohydrate group (first intervention): } 17 \pm 6 \text {, } \\
\quad 12 \pm 7,15 \pm 12 \mathrm{mU} / \mathrm{L}^{\mathrm{C}} \\
\text { - } 55 \% \text { Carbohydrate group (first intervention): } 24 \pm 13 \text {, } \\
22 \pm 6,26 \pm 10 \mathrm{mU} / \mathrm{L}^{\mathrm{C}} \\
\text { Differences between treatment groups were not significant } \\
(P>0.05)\end{array}$ & None/not reported \\
\hline
\end{tabular}

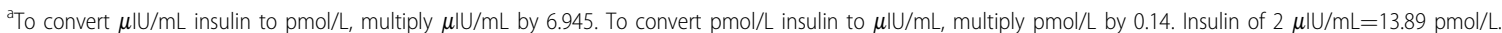

${ }^{\mathrm{b}}$ To convert $\mathrm{mmol} / \mathrm{L}$ glucose to $\mathrm{mg} / \mathrm{dL}$, multiply $\mathrm{mmol} / \mathrm{L}$ by 18.02 . To convert $\mathrm{mg} / \mathrm{dL}$ glucose to $\mathrm{mmol} / \mathrm{L}$, multiply $\mathrm{mg} / \mathrm{dL}$ by 0.0555 . Glucose of $6.1 \mathrm{mmol} / \mathrm{L}=109.92 \mathrm{mg} / \mathrm{dL}$.

${ }^{\mathrm{C}}$ To convert $\mathrm{mU} / \mathrm{L}$ insulin to pmol/L, multiply $\mathrm{mU} / \mathrm{L}$ by 6.954 . To convert pmol/L to $\mathrm{mU} / \mathrm{L}$, multiply $\mathrm{pmol} / \mathrm{L}$ by 0.144 . Insulin of $17 \mathrm{mU} / \mathrm{L}=118.065 \mathrm{pmol} / \mathrm{L}$.
}

\section{Effects of Dietary Interventions on Diabetes Outcomes}

Results from dietary intervention studies showed mixed effects on diabetes outcomes (Table 5). Findings from the lowglycemic index, energy restricted RCT showed no significant changes in fasting glucose levels after $6^{20}$ and $12^{19}$ months in the overall population, but 2-hour plasma glucose had declined significantly more for women in the intervention compared with the control group after 6 months. ${ }^{20}$ At the $12-$ month follow-up, fasting plasma glucose had significantly decreased in the intervention compared with the control group for women with baseline fasting insulin $\geq 2 \mu \mathrm{IU} / \mathrm{mL}$ (13.89 pmol/L) but not with baseline fasting insulin $<2 \mu \mathrm{IU} /$ $\mathrm{mL}(13.89 \mathrm{pmol} / \mathrm{L}){ }^{19}$ Findings from the crossover trial providing low-glycemic and high-fiber bread products showed no changes in fasting glucose, fasting insulin, and insulin sensitivity, but insulin secretion was lower after consuming the low-glycemic and high-fiber bread products for 3 weeks compared with before. ${ }^{27}$ An intervention, with a median follow-up of 51 months (ie, 4 years and 3 months) providing general dietary advice and dietitian contact did not significantly reduce T2DM risk, although the risk estimate indicated a trend toward a beneficial effect (relative risk 0.63 , $95 \% \mathrm{Cl} 0.35$ to 1.14 ) relative to the control group who received no dietitian contact. ${ }^{26} \mathrm{~A}$ crossover trial comparing different proportions of dietary energy from carbohydrates for a period of 12 weeks did not show a difference in fasting insulin levels between dietary interventions. ${ }^{25}$

\section{Associations between Dietary Intake and Diabetes Outcomes}

Findings from observational studies showed inverse associations between intake of a range of dietary factors and diabetes outcomes (Table 6). Prevalence of prediabetes was $34 \%{ }^{29}$ and $42 \%{ }^{29}$ in two cross-sectional studies, and incidence of T2DM ranged from 7\% at 6 to 12 weeks post-GDM pregnancy $^{28}$ to $16 \%$ at 14 years post-GDM pregnancy. ${ }^{21,22}$

In terms of overall dietary patterns, results based on the NSHII showed that a diet relatively low in carbohydrates was associated with higher T2DM risk, especially when fat and protein intake came largely from animal foods. ${ }^{22}$ Findings from the same study also demonstrated lower T2DM risk with higher a priori dietary pattern scores, including for the aMED, DASH, and aHEI, after adjustments for key 
Table 6. Results from observational studies included in a systematic review on associations of dietary intake with diabetes outcomes in women with a history of gestational diabetes

\begin{tabular}{|c|c|c|c|}
\hline Author(s), year & $\begin{array}{l}\text { Outcome } \\
\text { incidence }\end{array}$ & Results & Covariates included in analysis \\
\hline $\begin{array}{l}\text { Tobias and } \\
\text { colleagues, }^{24} \\
2018\end{array}$ & $\begin{array}{l}\mathrm{n}=172 \text { diabetes } \\
\text { cases and } 175 \\
\text { age-matched } \\
\text { controls } \\
\text { (nested-case } \\
\text { control study) }\end{array}$ & $\begin{array}{l}\text { Odds ratios for type } 2 \text { diabetes for top vs bottom } \\
\text { quartile of intake: } \\
\text { Isoleucine: } 5.78,95 \% \mathrm{Cl} 1.86-17.95(P \text { trend }=0.004) \\
\text { Leucine: } 4.66,95 \% \mathrm{Cl} 1.60-13.53 \text { ( } P \text { trend }=0.01) \\
\text { Valine: } 5.71,95 \% \mathrm{Cl} 1.85-17.60(P \text { trend }=0.009) \\
\text { Total branched-chain amino acids: } 4.63,95 \% \mathrm{Cl} \\
1.61-13.36(P \text { trend }=0.01)\end{array}$ & $\begin{array}{l}\text { Age, total energy intake, fasting status } \\
\leq 8 \mathrm{~h} \text {, alcohol intake, family history of } \\
\text { diabetes, menopausal status, and } \\
\text { current menopausal hormone } \\
\text { therapy use, physical activity, } \\
\text { smoking status, ethnicity, BMl } \\
\text { Alternative Healthy Eating Index-2010 } \\
\text { adherence dietary quality score }\end{array}$ \\
\hline $\begin{array}{l}\text { Mercier and } \\
\text { colleagues, }^{29} \\
2018\end{array}$ & $\begin{array}{l}\mathrm{n}=126(45 \%) \\
\text { abnormal } \\
\text { glucose } \\
\text { tolerance } \\
\text { cases, } \\
\text { including } \\
34 \% \\
\text { prediabetes } \\
\text { and } 11 \% \text { type } \\
2 \text { diabetes }\end{array}$ & $\begin{array}{l}\text { Women with abnormal glucose tolerance had } \\
\text { significantly lower fruit and vegetable servings } \\
\text { (mean } \pm \text { standard deviation: } 6.5 \pm 0.2) \text { and } \\
\text { vegetables servings ( } 3.9 \pm 0.2) \text { and tended to } \\
\text { have lower fruit servings }(2.6 \pm 0.2) \text { than women } \\
\text { with normal glucose tolerance }(7.4 \pm 0.2,4.5 \pm 0.2 \text {, } \\
\text { and } 3.0 \pm 0.1 \text {, respectively) ( } P=0.001, P=0.04 \text {, and } \\
P=0.10 \text {, respectively). } \\
\text { Odds ratios for abnormal glucose tolerance: } \\
\text { Fruit and vegetables per } 1 \text { serving: } 0.88,95 \% \mathrm{Cl} \\
\quad 0.81-0.97 \\
\text { Vegetables per } 1 \text { serving: } 0.88,95 \% \mathrm{Cl} 0.78-1.00 \\
\text { Fruit per } 1 \text { serving: } 0.88,95 \% \mathrm{Cl} 0.76-1.02 \\
\text { Fruit and vegetables }<7 \mathrm{vs} \geq 7 \text { serving: } 1.84,95 \% \mathrm{Cl} \\
1.13-3.00\end{array}$ & Age and BMI \\
\hline $\begin{array}{l}\text { Andersson-Hall } \\
\text { and } \\
\text { colleagues, }{ }^{30} \\
2018\end{array}$ & $\begin{array}{l}\mathrm{n}=32(23.4 \%) \\
\text { impaired } \\
\text { glucose } \\
\text { tolerance } \\
\text { cases and } \\
\mathrm{n}=17(12.4 \%) \\
\text { type } 2 \\
\text { diabetes } \\
\text { cases }\end{array}$ & $\begin{array}{l}\text { There were no differences between groups in terms } \\
\text { of energy, carbohydrate, protein and fat intake, } \\
\text { meal frequency, and proportion of vegetable oil } \\
\text { used for cooking }(P>0.05) \text {. Compared with women } \\
\text { with normal glucose tolerance, women with } \\
\text { impaired glucose tolerance }(P=0.01) \text { and type } 2 \\
\text { diabetes }(P=0.01) \text { had lower proportions of butter } \\
\text { used for cooking, and women with type } 2 \text { diabetes } \\
\text { also had higher proportion of margarine used for } \\
\text { cooking ( } P=0.004) \text {. }\end{array}$ & Age, ethnicity, BMI \\
\hline $\begin{array}{l}\text { Bao and } \\
\text { colleagues, }^{21} \\
2016\end{array}$ & $\begin{array}{l}\mathrm{n}=614(16 \%) \\
\text { type } 2 \\
\text { diabetes } \\
\text { cases }\end{array}$ & $\begin{array}{l}\text { Hazard ratios for type } 2 \text { diabetes: } \\
\text { Total iron intake: } 1.64,95 \% \mathrm{Cl} 1.20-2.25 \text { for top } \\
(37.2 \mathrm{mg} / \mathrm{d}) \text { vs bottom }(11.6 \mathrm{mg} / \mathrm{d}) \text { category } \\
\text { Supplemental iron intake: } 1.83,95 \% \mathrm{Cl} 1.25-2.70 \text { for } \\
\text { top }(\geq 30 \mathrm{mg} / \mathrm{d}) \text { vs bottom }(0 \mathrm{mg} / \mathrm{d}) \text { category } \\
\text { Dietary heme iron intake: } 1.80,95 \% \mathrm{Cl} 1.18-2.74 \text { for } \\
\text { top }(1.5 \mathrm{mg} / \mathrm{d}) \text { vs bottom }(0.7 \mathrm{mg} / \mathrm{d}) \text { category } \\
\text { Dietary nonheme iron intake: } 0.71,95 \% \mathrm{Cl} 0.51-1.00 \\
\text { for top }(16.6 \mathrm{mg} / \mathrm{d}) \text { vs bottom }(9.0 \mathrm{mg} / \mathrm{d}) \\
\text { category }\end{array}$ & $\begin{array}{l}\text { Age, parity, BMI, age at first birth, } \\
\text { ethnicity, oral contraceptive use, } \\
\text { menopausal status, cigarette } \\
\text { smoking, alcohol intake, physical } \\
\text { activity, ratio of polyunsaturated fat } \\
\text { to saturated fat, total energy intake, } \\
\text { saturated fat, trans fat, cholesterol, } \\
\text { animal and vegetable protein, } \\
\text { glycemic load, cereal fiber, calcium, } \\
\text { magnesium, vitamin C, } \\
\text { supplemental iron (for heme and } \\
\text { nonheme iron analysis), and total } \\
\text { dietary iron (for supplemental iron } \\
\text { analysis) }\end{array}$ \\
\hline
\end{tabular}


Table 6. Results from observational studies included in a systematic review on associations of dietary intake with diabetes outcomes in women with a history of gestational diabetes (continued)

\begin{tabular}{|c|c|c|c|}
\hline Author(s), year & $\begin{array}{l}\text { Outcome } \\
\text { incidence }\end{array}$ & Results & Covariates included in analysis \\
\hline $\begin{array}{l}\text { Bao and } \\
\text { colleagues, }{ }^{22} \\
2016\end{array}$ & $\begin{array}{c}\mathrm{n}=722(16 \%) \\
\text { type } 2 \\
\text { diabetes } \\
\text { cases }\end{array}$ & $\begin{array}{l}\text { Hazard ratios for type } 2 \text { diabetes for top vs bottom } \\
\text { quintiles of diet scores (confounder and } \\
\text { confounder }+ \text { BMl-adjusted models, } \\
\text { respectively): } \\
\text { Overall low-carbohydrate diet score: } 2.13,95 \% \mathrm{Cl} \\
1.65-2.76 \text { ( } P \text { trend } \leq 0.001) \text { and } 1.36,95 \% \mathrm{Cl} 1.04- \\
1.78 \text { ( } P \text { trend }=0.003) \\
\text { Animal low-carbohydrate diet score: } 2.18,95 \% \mathrm{Cl} \\
1.68-2.83(P \text { trend } \leq 0.001) \text { and } 1.40,95 \% \mathrm{Cl} 1.06- \\
1.84(P \text { trend }=0.004) \\
\text { Vegetable-carbohydrate diet score: } 1.29,95 \% \mathrm{Cl} \\
1.00-1.67(P \text { trend }=0.14) \text { and } 1.19,95 \% \mathrm{Cl} 0.91- \\
1.55(P \text { trend }=0.50)\end{array}$ & $\begin{array}{l}\text { Age, parity, BMI, age at first birth, } \\
\text { ethnicity, oral contraceptive use, } \\
\text { menopausal status, cigarette } \\
\text { smoking, alcohol intake, physical } \\
\text { activity, family history of diabetes, } \\
\text { total energy intake, glycemic index }\end{array}$ \\
\hline $\begin{array}{l}\text { Tobias and } \\
\text { colleagues, } \\
2012\end{array}$ & $\begin{array}{c}\mathrm{n}=491(11 \%) \\
\text { type } 2 \\
\text { diabetes } \\
\text { cases }\end{array}$ & $\begin{array}{l}\text { Hazard ratios for type } 2 \text { diabetes for top vs bottom } \\
\text { quartile of dietary pattern scores (confounder } \\
\text { and confounder }+ \text { BMl-adjusted models, } \\
\text { respectively): } \\
\text { Alternate Mediterranean diet: } 0.60,95 \% \mathrm{Cl} 0.44- \\
0.82(P \text { trend }=0.002) \text { and } 0.76,95 \% \mathrm{Cl} 0.55-1.05 \\
(P \text { trend }=0.13) \\
\text { Dietary Approaches to Stop Hypertension: } 0.54 \text {, } \\
95 \% \mathrm{Cl} 0.39-0.73(P \text { trend } \leq 0.001) \text { and } 0.68,95 \% \\
\text { Cl } 0.49-0.94(P \text { trend }=0.04) \\
\text { Alternate Healthy Eating Index: } 0.43,95 \% \mathrm{Cl} 0.31- \\
0.59(P \text { trend } \leq 0.001) \text { and } 0.65,95 \% \mathrm{Cl} 0.46-0.92 \\
(P \text { trend }=0.01)\end{array}$ & $\begin{array}{l}\text { Age, total energy intake, parity, age at } \\
\text { first birth, race/ethnicity, parental } \\
\text { history of type diabetes, oral } \\
\text { contraceptive use, menopausal } \\
\text { status, smoking status, physical } \\
\text { activity, alcohol intake, BMI } \\
\text { (breastfeeding was not included in } \\
\text { the models, but it was mentioned } \\
\text { that this did not alter the findings) }\end{array}$ \\
\hline $\begin{array}{l}\text { Kim and } \\
\text { colleagues, }^{28} \\
2011\end{array}$ & $\begin{array}{l}\mathrm{n}=161(42.3 \%) \\
\text { prediabetes } \\
\text { cases } \\
\mathrm{n}=27(7.1 \%) \\
\text { type } 2 \\
\text { diabetes } \\
\text { cases }\end{array}$ & $\begin{array}{l}\text { Compared with women with normal glucose } \\
\text { tolerance, women who developed prediabetes } \\
\text { and type } 2 \text { diabetes had higher intakes of total } \\
\text { energy; total and animal protein; and total, } \\
\text { animal, and monounsaturated fat. There were no } \\
\text { differences in intake of carbohydrates, plant } \\
\text { protein, plant, saturated-, polyunsaturated-, and } \\
\text { n-3 and n-6 fatty acids, and fiber }\end{array}$ & Prepregnancy BMI \\
\hline
\end{tabular}

confounders such as age, ethnicity, BMI, parity, lifestyle, and other dietary factors. ${ }^{23}$ Although adjustment for BMI attenuated the risk estimates, statistically significant associations remained when BMI was added to the model. ${ }^{22,23} \mathrm{~A}$ nested case-control study within the NHSII found higher intakes of branched chain amino acids were associated with higher risk of T2DM. ${ }^{25}$ The NHSII also showed that women with the highest compared with the lowest intakes of total iron (dietary and supplemental), supplemental iron, and dietary heme iron were at higher risk of developing T2DM, whereas high dietary nonheme iron intake was associated with a lower risk after adjustment for key confounders. ${ }^{21}$ Higher intake of fruit and vegetables was associated with lower odds of abnormal glucose tolerance in Canadian women based on a cross-sectional analysis adjusted for age and BMI. ${ }^{29}$ Kim and colleagues ${ }^{28}$ found in their cross-sectional study that Korean women who had developed prediabetes or T2DM had higher intakes of total energy; total and animal protein; and total, animal, and monounsaturated fat; after adjustment for prepregnancy BMI. ${ }^{29}$ The Swedish cross-sectional study; however, did not find differences between women with normal glucose tolerance, impaired glucose tolerance, and T2DM in terms of energy and macronutrient intake, after adjustment for key confounders. $^{30}$ This study showed that, compared with women with normal glucose tolerance, women with impaired glucose tolerance or T2DM had lower proportions of butter used for 
cooking, and women with T2DM had higher proportion of margarine used for cooking. ${ }^{30}$

\section{Quality Assessment}

Intervention Studies. Based on the Cochrane risk of bias tool, intervention studies were at high risk of selection bias (random sequence generation [40\% of studies], poor allocation concealment [ $40 \%$ of studies], and performance bias [ $60 \%$ of studies]) (Figures 4 and 5, available at www.jandonline. org). All five studies had unclear risk of detection and attrition bias, whereas most studies were scored as low risk of reporting bias.

Observational Studies. Quality assessment scores for observational studies ranged from five to seven (out of nine indicating the lowest degree of bias) based on the NewcastleOttawa Scale (Table 7, available at www.jandonline.org). Main concerns were representativeness of the study sample (no random sample of women in the community), comparability of exposed and unexposed participants based on design or analysis (the two cross-sectional studies did not adjust for potential key confounding factors, including parity, family history of diabetes, smoking, physical activity, and other dietary factors), and adequacy of follow-up rate (studies either did not report on the follow-up rate, or did not describe the lost population in the case that the follow-up rate was $<90 \%$ ).

\section{DISCUSSION}

\section{Summary of Main Findings}

This systematic review identified a limited number of intervention and observational studies that examined the role of diet in the prevention of diabetes among women with previous GDM. Five articles that reported on four small intervention studies found no strong evidence for a beneficial effect on glucose and insulin levels and on T2DM risk. Four articles that reported on associations with T2DM risk in a large prospective cohort study showed adverse associations for higher intakes of branched-chain amino acids, total and heme iron, and a low-carbohydrate diet, and protective associations for higher adherence to aMED, aHEI, and DASH diet scores. Cross-sectional findings from one study showed lower intakes of fruit and vegetables among women with abnormal compared with normal glucose tolerance, whereas findings from two cross-sectional studies on total energy, protein, and fat intake in relation to prediabetes and impaired glucose tolerance were inconsistent. These observational findings were adjusted for confounding factors, including BMI.

\section{Interpretation}

The inconclusive findings on the effectiveness of dietary interventions for diabetes prevention in women with a GDM history are consistent with previous systematic reviews of RCTs. ${ }^{7-10}$ Whereas previous reviews reported on only two dietalone interventions, ${ }^{20,26}$ this review identified five articles that reported on four studies. ${ }^{19,20,25-27}$ These trials were based on small samples and not powered to detect significant differences. ${ }^{19,20,25-27}$ These trials also varied in terms of intervention content (advice focused on carbohydrate quality, 19,20,27 carbohydrate quantity ${ }^{25}$ or overall diet in line with national guidelines $\left.^{26}\right)$, and examined different outcome measures (glucose, ${ }^{19,20,27}$ insulin, ${ }^{25,27}$ or T2DM ${ }^{26}$ ). Although findings from intervention studies generally indicated trends toward beneficial effects, the overall quality of these trials was rated as either unclear or high risk of bias. Based on the current evidence, a specific dietary intervention for diabetes prevention in women with prior GDM can therefore not be recommended. Previous systematic reviews have also consistently concluded that evidence for an effect of combined diet and physical activity interventions is inconclusive, ${ }^{7-10}$ with the exception of strong evidence from the Diabetes Prevention Program. ${ }^{31}$ Findings from that intensive intervention that focused on diet and physical activity to achieve and maintain weight loss of at least $7 \%$ of initial body weight showed $>50 \%$ reduction in the risk of developing T2DM in women at high risk of T2DM including women with previous $\mathrm{GDM}^{31}$; however, this personalised lifestyle intervention is unlikely to be feasible for implementation in routine care. As a limited number of studies have examined diet-alone and physical activity-alone interventions, it remains unclear which diabetes prevention approach would be most effective for women with a GDM history. ${ }^{7-10}$ It has been suggested based on combined diet and physical activity interventions that changes in diet were more often successfully implemented compared with changes in physical activity. ${ }^{10}$ This may be explained by barriers related to being active and engaging in physical activity such as lack of time and energy, emotional distress, physical discomfort, and lack of child care support. ${ }^{13-15}$ Further studies should explore the feasibility and acceptability of dietary interventions for women following childbirth, and future RCTs should accommodate barriers to improve intervention compliance among new mothers.

Findings from observational studies identified in this review showed adverse associations with diabetes outcomes for higher intakes of branched-chain amino acids,,$^{24}$ total and heme iron, ${ }^{21}$ and a diet relatively low in carbohydrates and high in animal fat and protein, ${ }^{22}$ and beneficial associations for diets rich in fruit, vegetables, nuts, fish, and legumes, and low in red and processed meats and sugar-sweetened beverages. ${ }^{23,29}$ These results support dietary recommendations for the general population $^{32,33}$ and for diabetes prevention. ${ }^{34}$ Findings from observational studies were rated to be of medium to high quality (score of 5 to 7 out of 9), and observed associations were based on analyses adjusted for $\mathrm{BMI}^{21-24,28,29}$ and physical activity. ${ }^{21-24}$ These findings therefore suggest that, whereas BMI partly attenuated the associations, ${ }^{22,23}$ consuming a healthy diet may help reduce T2DM risk independent of BMI.

\section{Implications for Practice and Research}

There is strong evidence that the majority of T2DM cases in the general population can be prevented through a healthy lifestyle, ${ }^{34,35}$ yet lifestyle interventions targeting women with prior GDM have only recently emerged. With the growing rates of GDM, T2DM, and the associated health and economic burden worldwide, ${ }^{5,6}$ interventions that successfully prevent T2DM in this high-risk group are critical. Postnatal screening following a GDM pregnancy represents an important opportunity for clinicians and health professionals to educate, counsel and engage women in prevention programs that may reduce their risk of progressing to diabetes. However, the uptake of postnatal follow-up by women with GDM is poor with $<25 \%$ of women returning for a postnatal glucose tolerance test, mainly due to lack of time and awareness of risks. ${ }^{36}$ Previous studies have shown poor diet quality and 
low adherence to dietary recommendations among women with a GDM history, ${ }^{37,38}$ and a significant knowledge gap on future health risks and the recommended lifestyle modifications. $^{38}$ Although a causal effect of diet on T2DM following GDM has not been established, and further research is needed to develop effective postnatal preventive interventions, it seems prudent to inform women about their future risk of developing T2DM and the potential benefit of a healthy diet.

\section{Strengths and Limitations}

Strengths of this systematic review include the focus on dietary intake, which has not been distinguished from effects of physical activity in previous systematic reviews. Moreover, this review includes all study designs (both intervention and observational), providing a more comprehensive overview of the current evidence. This review is restricted by lack of highquality dietary intervention studies. Further evidence from postpartum dietary RCTs that follow women for a longer period of time are needed to confirm findings from observational studies. Current observational findings suggest that future RCTs should not only focus on carbohydrate quality and quantity, but also on other aspects of the overall diet, including increasing intake of fruit, vegetables, and other plant-based foods, and reducing animal products such as red and processed meats.

\section{CONCLUSIONS}

This systematic review indicates a lack of high quality dietary RCT evidence for the prevention of diabetes among women with prior GDM. Findings from observational studies have shown beneficial associations of several nutrients, foods and dietary patterns in line with current dietary recommendations and suggest diet may play a role in the prevention of diabetes among women with prior GDM. Further large prospective dietary RCTs that are acceptable to new mothers are needed to confirm if dietary modifications in line with healthy eating guidelines reduce the risk of T2DM among women following a GDM pregnancy.

\section{References}

1. Section 13. Diabetes and reproductive health. In: General Practice Management of Type 2 Diabetes: 2016-18. East Melbourne, Victoria, Australia: The Royal Australian College of General Practitioners; 2016.

2. Zhu Y, Zhang C. Prevalence of gestational diabetes and risk of progression to type 2 diabetes: A global perspective. Curr Diab Rep. 2016;16(1):7.

3. Dabelea D, Snell-Bergeon JK, Hartsfield CL, Bischoff KJ, Hamman RF, McDuffie RS. Increasing prevalence of gestational diabetes mellitus (GDM) over time and by birth cohort: Kaiser Permanente of Colorado GDM Screening Program. Diabetes Care. 2005;28(3):579-584.

4. Kim C, Newton KM, Knopp RH. Gestational diabetes and the incidence of type 2 diabetes: A systematic review. Diabetes Care. 2002;25(10):1862-1868.

5. World Health Organization. Global report on diabetes. 2016. http:// www.who.int/iris/handle/10665/204871. Accessed August 19, 2019.

6. International Diabetes Federation. IDF diabetes atlas, 8th ed. 2017. http://www.diabetesatlas.org. Accessed August 19, 2019.

7. Morton S, Kirkwood S, Thangaratinam S. Interventions to modify the progression to type 2 diabetes mellitus in women with gestational diabetes: A systematic review of literature. Curr Opin Obstet Gynecol. 2014;26(6):476-486.

8. Gilinsky AS, Kirk AF, Hughes AR, Lindsay RS. Lifestyle interventions for type 2 diabetes prevention in women with prior gestational diabetes: A systematic review and meta-analysis of behavioural, anthropometric and metabolic outcomes. Prev Med Rep. 2015;2:448461.

9. Guo J, Chen JL, Whittemore R, Whitaker E. Postpartum lifestyle interventions to prevent type 2 diabetes among women with history of gestational diabetes: A systematic review of randomized clinical trials. J Womens Health. 2016;25(1):38-49.

10. Pedersen ALW, Terkildsen Maindal H, Juul L. How to prevent type 2 diabetes in women with previous gestational diabetes? A systematic review of behavioural interventions. Prim Care Diabet. 2017;11(5):403-413.

11. Elliott-Sale KJ, Barnett CT, Sale C. Exercise interventions for weight management during pregnancy and up to 1 year postpartum among normal weight, overweight and obese women: A systematic review and meta-analysis. Br J Sports Med. 2015;49(20):1336-1342.

12. Amorim Adegboye AR, Linne YM. Diet or exercise, or both, for weight reduction in women after childbirth. Cochrane Database Syst Rev. 2013;7:Cd005627.

13. Infanti JJ, O'Dea A, Gibson I, McGuire BE, Newell J, Glynn LG, et al. Reasons for participation and non-participation in a diabetes prevention trial among women with prior gestational diabetes mellitus (GDM). BMC Med Res Methodol. 2014;14:13.

14. Montgomery KS, Bushee TD, Phillips JD, et al. Women's challenges with postpartum weight loss. Matern Child Health J. 2011;15(8): 1176-1184.

15. van der Pligt P, Ball K, Hesketh KD, Crawford D, Teychenne M, Campbell K. The views of first time mothers completing an intervention to reduce postpartum weight retention: A qualitative evaluation of the mums OnLiNE study. Midwifery. 2018;56:23-28.

16. Higgins JPT, Green S, eds. Cochrane Handbook for Systematic Reviews of Interventions Version 5.1.0. 2011. www.cochrane-handbook.org. Accessed August 19, 2019.

17. Liberati A, Altman DG, Tetzlaff J, et al. The PRISMA statement for reporting systematic reviews and meta-analyses of studies that evaluate health care interventions: Explanation and elaboration. PLoS Med. 2009;6(7):e1000100.

18. Wells GA, Shea B, O'Connell D, et al. The Newcastle-Ottawa Scale (NOS) for assessing the quality of nonrandomised studies in metaanalyses. 2009. http://www.ohri.ca/programs/clinical_epidemiology/ oxford.asp. Accessed September 4, 2019.

19. Ghani RA, Shyam S, Arshad F, et al. The influence of fasting insulin level in post-gestational diabetes mellitus women receiving lowglycaemic-index diets. Nutr Diabet. 2014;4:e107.

20. Shyam S, Arshad F, Abdul Ghani R, et al. Low glycaemic index diets improve glucose tolerance and body weight in women with previous history of gestational diabetes: A six months randomized trial. Nutr J. 2013;12(1):68.

21. Bao W, Chavarro JE, Tobias DK, et al. Long-term risk of type 2 diabetes in relation to habitual iron intake in women with a history of gestational diabetes: a prospective cohort study. Am J Clin Nutr. 2016;103(2):375-381.

22. Bao W, Li S, Chavarro JE, et al. Low carbohydrate-diet scores and long-term risk of type 2 diabetes among women with a history of gestational diabetes mellitus: A prospective cohort study. Diabetes Care. 2016;39(1):43-49.

23. Tobias DK, Hu FB, Chavarro J, Rosner B, Mozaffarian D, Zhang C. Healthful dietary patterns and type 2 diabetes mellitus risk among women with a history of gestational diabetes mellitus. Arch Intern Med. 2012;172(20):1566-1572.

24. Tobias DK, Clish C, Mora S, et al. Dietary intakes and circulating concentrations of branched-chain amino acids in relation to incident type 2 diabetes risk among high-risk women with a history of gestational diabetes mellitus. Clin Chem. 2018;64(8):1203-1210.

25. Peterson CM, Jovanovic-Peterson L. Randomized crossover study of $40 \%$ vs. $55 \%$ carbohydrate weight loss strategies in women with previous gestational diabetes mellitus and non-diabetic women of 130-200\% ideal body weight. J Am Coll Nutr. 1995;14(4):369-375.

26. Wein P, Beischer N, Harris C, Permezel M. A trial of simple versus intensified dietary modification for prevention of progression to diabetes mellitus in women with impaired glucose tolerance. Aust $N$ Z J Obstet Gynaecol. 1999;39(2):162-166.

27. Ostman EM, Frid AH, Groop LC, Bjorck IM. A dietary exchange of common bread for tailored bread of low glycaemic index and rich in dietary fibre improved insulin economy in young women with impaired glucose tolerance. Eur J Clin Nutr. 2006;60(3):334-341. 
28. Kim SH, Kim MY, Yang JH, et al. Nutritional risk factors of early development of postpartum prediabetes and diabetes in women with gestational diabetes mellitus. Nutrition. 2011;27(7-8):782-788.

29. Mercier R, Perron J, Weisnagel SJ, Robitaille J. Associations between fruit and vegetables intake and abnormal glucose tolerance among women with prior gestational diabetes mellitus. Eur J Nutr. 2019;58(2):689-696.

30. Andersson-Hall U, Carlsson NG, Sandberg AS, Holmang A. Circulating linoleic acid is associated with improved glucose tolerance in women after gestational diabetes. Nutrients. 2018;10(1629):1-17.

31. Knowler WC, Barrett-Connor E, Fowler SE, et al. Reduction in the incidence of type 2 diabetes with lifestyle intervention or metformin. N Engl J Med. 2002;346(6):393-403.

32. US Departments of Health and Human Services and Agriculture. 2015-2020 Dietary Guidelines for Americans. 8th edition. 2015 https://health.gov/dietaryguidelines/2015/guidelines/. Accessed August 19, 2019.

33. National Health and Medical Research Council. Australian dietary guidelines. 2013. https://www.eatforhealth.gov.au/sites/default/ files/content/n55_australian_dietary_guidelines.pdf.

Accessed August 19, 2019

34. American Diabetes Association. Prevention or delay of type 2 diabetes. Sec. 4. In Standards of Medical Care in Diabetes - 2016. Diabetes Care. 2016;39(suppl 1):S36-S38.

35. Hu FB, Manson JE, Stampfer MJ, et al. Diet, lifestyle, and the risk of type 2 diabetes mellitus in women. N Engl J Med. 2001;345(11):790797.

36. Sanderson H, Loveman E, Colquitt J, Royle P, Waugh N, Tan BK Improving uptake of postnatal checking of blood glucose in women who had gestational diabetes mellitus in universal healthcare settings: A systematic review. J Clin Med. 2018;8(4): $1-15$.

37. Morrison MK, Koh D, Lowe JM, et al. Postpartum diet quality in Australian women following a gestational diabetes pregnancy. Eur J Clin Nutr. 2012;66(10):1160-1165.

38. Jones EJ, Roche CC, Appel SJ. A review of the health beliefs and lifestyle behaviors of women with previous gestational diabetes. J Obstet Gynecol Neonatal Nurs. 2009;38(5):516-526.

\section{AUTHOR INFORMATION}

E. D'Arcy is a research and evaluation officer, Health Intelligence Unit, NSW Health, Bathurst, New South Wales, Australia; at the time of conceptualizing the study, she was a lecturer, Griffith University, Gold Coast Campus, Queensland, Australia. At the time of the study, J. Rayner was a nutrition and dietetics honors student, Griffith University, Gold Coast Campus, Queensland, Australia. A. Hodge is an associate professor and principal fellow, Cancer Epidemiology Division, Cancer Council Victoria, Melbourne, Victoria, Australia. L. J. Ross is a lecturer, School of Allied Health Sciences, Nutrition and Dietetics, Gold Coast Campus, Griffith University, Southport, Queensland, Australia, and Menzies Health Institute Queensland, Griffith University, Gold Coast, Queensland, Australia. D. A. J. M. Schoenaker is a research fellow, School of Medicine, Faculty of Science, Medicine and Health, and Illawarra Health and Medical Research Institute, University of Wollongong, Wollongong, New South Wales, Australia, and an adjunct fellow, The Robinson Research Institute and Discipline of Obstetrics and Gynaecology, University of Adelaide, Adelaide, South Australia, Australia; at the time of the study, she was a senior research officer, Centre for Behavioural Research in Cancer, Cancer Council Victoria, Melbourne, Victoria, Australia.

Address correspondence to: Danielle A. J. M. Schoenaker, PhD, School of Medicine, Faculty of Science, Medicine and Health, and Illawarra Health and Medical Research Institute, University of Wollongong, Northfields Ave, Wollongong, NSW 2500, Australia. E-mail: danis@uow.edu.au

\section{STATEMENT OF POTENTIAL CONFLICT OF INTEREST}

No potential conflict of interest was reported by the authors.

\section{FUNDING/SUPPORT}

There is no funding to disclose.

The review was registered with PROSPERO International prospective register of systematic reviews (CRD42018090887) (http://www.crd.yorkac.uk/ PROPSERO).

\section{AUTHOR CONTRIBUTIONS}

E. D'Arcy, J. Rayner, and D. A. J. M. Schoenaker conducted the research. E. D'Arcy and D. A. J. M. Schoenaker analyzed the data, wrote the manuscript, and had primary responsibility for the final content of the manuscript. All authors designed the research and read and approved the final manuscript. 


\begin{tabular}{|c|c|}
\hline Search no. & Search term ${ }^{a}$ \\
\hline 1 & gestational diabetes:ti,ab \\
\hline 2 & GDM:ti,ab \\
\hline 3 & pregnancy diabetes mellitus:ti,ab \\
\hline 4 & pregnancy induced diabetes:ti,ab \\
\hline 5 & 1 or 2 or 3 or 4 \\
\hline 6 & history:ti,ab \\
\hline 7 & medical history:ti,ab \\
\hline 8 & previous*:ti,ab \\
\hline 9 & 6 or 7 or 8 \\
\hline 10 & $\operatorname{diet}^{*}: t i, a b$ \\
\hline 11 & 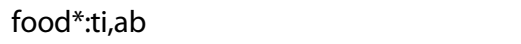 \\
\hline 12 & carbohydrate*:ti,ab \\
\hline 13 & nutrition*:ti,ab \\
\hline 14 & glycemic index:ti,ab \\
\hline 15 & Gl:ti,ab \\
\hline 16 & 10 or 11 or 12 or 13 or 14 or 15 \\
\hline 17 & type 2 diabetes:ti,ab \\
\hline 18 & diabetes:ti,ab \\
\hline 19 & DM:ti,ab \\
\hline 20 & T2DM:ti,ab \\
\hline 21 & impaired glucose tolerance:ti,ab \\
\hline 22 & prediabetes:ti,ab \\
\hline 23 & impaired fasting glucose:ti,ab \\
\hline 24 & 17 or 18 or 19 or 20 or 21 or 22 or 23 \\
\hline 25 & 5 and 9 and 16 and 24 \\
\hline
\end{tabular}

${ }^{\text {a }}$ Restricted to English language and human populations.

Similar searches were conducted in all other databases.

Figure 2. Search strategy for Embase in a systematic review on effects of dietary interventions and associations of dietary intake with diabetes outcomes in women with a history of gestational diabetes. $\mathrm{CINAHL}=$ Cumulative Index to Nursing and Allied Health Literature. 
Table 3. Intervention goals, content, and compliance, and diabetes outcome assessment in intervention studies included in a systematic review on effects of dietary interventions on diabetes outcomes in women with a history of gestational diabetes

\begin{tabular}{|c|c|}
\hline $\begin{array}{l}\text { Author(s), } \\
\text { year }\end{array}$ & Intervention goals and content \\
\hline $\begin{array}{l}\text { Ghani and } \\
\text { colleagues, } \\
2014\end{array}$ & $\begin{array}{l}\text { (1) Low glycemic index intervention group: } \\
\text { Women received conventional healthy } \\
\text { dietary recommendations including nutrition } \\
\text { education at baseline through a structured 1- } \\
\text { on-1 session with a research nutritionist, } \\
\text { sample menus, and take-home reference } \\
\text { booklets. Education sessions emphasised } \\
\text { restriction of energy and fat intake and } \\
\text { encouraged increases in dietary fiber intake. } \\
\text { The goal was to achieve a } 5 \%-7 \% \text { reduction in } \\
\text { body weight when BMl }>23 \text { or to maintain } \\
\text { current weight when BMI }<23 \text {. Energy } \\
\text { requirements were calculated, and women } \\
\text { with BMI > } 23 \text { had a } 500-k c a l \text { energy } \\
\text { restricted diet, capped at } 1,800 \text { kcal/d. } \\
\text { Women were followed-up quarterly, and } \\
\text { received fortnightly reminders using e-mail or } \\
\text { short messaging services reinforcing } \\
\text { concepts of healthy living and motivating } \\
\text { women to comply with the intervention. } \\
\text { Women were also encouraged to engage in } \\
\text { moderate physical activity for } 30 \text { min at least } \\
5 \text { times a week. } \\
\text { In addition to conventional healthy dietary } \\
\text { recommendations, women received low } \\
\text { glycemic index education, including advice } \\
\text { on how to choose low glycemic index options } \\
\text { in place of high glycemic index staples like } \\
\text { bread, rice, and breakfast cereal. Women } \\
\text { were asked to restrict rice intake to once per } \\
\text { recoived conventional healthy dietary } \\
\text { rechendations only }\end{array}$ \\
\hline
\end{tabular}

Shyam and Similar to Ghani and colleagues, ${ }^{19} 2014$ colleagues, $^{20}$

2013

Intervention compliance

Compliance was monitored through assessments of dietary intake (3-d dietary records at baseline, 3 and $6 \mathrm{mo}$ ), and nutrition knowledge assessment pertaining to the group-specific concepts. After 6 mo, mean percentage of calories from carbohydrates, and glycemic index and glycemic load were significantly lower in the intervention compared with the control group. Fiber intake was significantly higher in the intervention group
Similar to Ghani and colleagues, ${ }^{19}$ 2014
Outcome assessment and criteria

Plasma glucose was measured on blood samples drawn in the fasting state (12 h).

Diagnostic criteria: Not applicable (continuous outcome)

\footnotetext{
Plasma glucose was measured on blood samples drawn in the fasting state (12 h). 2-h postload blood glucose was measured after a $75 \mathrm{~g}$ oral glucose tolerance test. Diagnostic criteria: Not applicable (continuous outcome)

(continued on next page)
} 
Table 3. Intervention goals, content, and compliance, and diabetes outcome assessment in intervention studies included in a systematic review on effects of dietary interventions on diabetes outcomes in women with a history of gestational diabetes (continued)

Author(s), year Intervention goals and content

(1) Low glycemic index and high fiber bread products

Östman and colleagues, $^{27}$ 2006

(2) High glycemic index and low-fiber bread products

Participants were asked to eat 7 slices of low glycemic index/high-fiber or high-glycemic index/low-fiber bread across 3 meals/d. Participants were also supplied with butter, cheese, and ham to be used on the bread in amounts according to written instructions. Apart from the bread meals, participants were asked to maintain their habitual diet throughout the study, but were not allowed to eat any other type of bread

Wein and colleagues, $^{26}$ 1999

Peterson and colleagues, $^{25}$ 1995
(1) Lifestyle intervention: Women were given dietary questionnaires and a standard dietary advice sheet ("Target on Healthy Eating") and in addition had 3-monthly telephone contacts with a dietitian.

(2) Control group: Women were given dietary questionnaires and a standard dietary advice sheet ("Target on Healthy Eating") only.

Both groups received a reminder of the need for regular exercise

(1) Dietary intervention 1: $40 \%$ carbohydrates

(2) Dietary intervention 2: 55\% carbohydrates Women received nutritional supplement bars for breakfast, lunch, and snacks. These were identically wrapped, each contained $180 \mathrm{kcal}$ with $20 \%$ protein, and either $40 \%$ or $55 \%$ carbohydrates

A meal plan for dinner was provided

The daily energy prescription consisted of 16.5 $\mathrm{kcal} / \mathrm{kg}$ body weight at entry into the trial with a mean energy consumption of 1,500 $\mathrm{kcal} / 24 \mathrm{~h}$ for both groups

The anticipated weight loss was calculated at 1 to $2 \mathrm{lb} / \mathrm{wk}$
Intervention compliance

Not reported

not reported

A diet score (based on the fat, residue, and sugar content of the diet assessed through diet history) was assessed and not significantly different at trial entry between control and intervention groups, and were also not different at final assessment (diet improved in both groups)

Women were instructed to maintain a daily diary wherein they recorded all foods consumed by time of day. These were reviewed every 1 or 2 wk. All participants showed significant weight loss during the first $6 \mathrm{wk}$ regardless of treatment assignment. Weight loss attenuated during the second $6 \mathrm{wk}$ of the study also regardless of treatment assignment. The diet score at enrolment did not differ between the intervention and control groups (3.1 and 3.2, respectively). There was improvement in diet scores, but this was comparable in the intervention and control groups

(0.64 and 0.56; $P=0.32$ )
Outcome assessment and criteria

Fasting glucose and insulin were measured on blood samples drawn in the fasting state. Insulin secretion and insulin sensitivity were assessed based on an intravenous glucose tolerance test followed by a euglycemichyperinsulinemic clamp.

Diagnostic criteria: Not applicable (continuous outcomes)

Type 2 diabetes was assessed using an oral glucose tolerance test after an overnight fast

Diagnostic criteria: World Health

Organization guidelines 1985

Serum fasting insulin was assessed at baseline and after 6 wk and 12 wk

Diagnostic criteria: Not applicable (continuous outcome) 
Table 4. Diet and diabetes outcome assessment in observational studies included in a systematic review on associations of dietary intake with diabetes outcomes in women with a history of gestational diabetes

\begin{tabular}{|c|c|c|}
\hline Author(s), year & Exposure assessment & Outcome assessment and criteria \\
\hline $\begin{array}{l}\text { Mercier and } \\
\text { colleagues, } \\
2018\end{array}$ & $\begin{array}{l}\text { Validated } 91 \text {-item food } \\
\text { frequency questionnaire } \\
\text { reflecting past month } \\
\text { consumption } \\
\text { Administered by a registered } \\
\text { dietitian during a clinical visit }\end{array}$ & $\begin{array}{l}\text { Glycemic measurements were obtained during each woman's visit at } \\
\text { the clinical investigation unit } \\
\text { Diagnostic criteria: Canadian Diabetes Association Guidelines } 2013 \\
\text { Impaired fasting glucose: fasting glucose } 6.1 \text { to } 6.9 \mathrm{mmol} / \mathrm{L}^{\mathrm{a}} \text { and } \\
\text { normal 2-h postoral glucose tolerance test glucose }<7.8 \mathrm{mmol} / \mathrm{L}^{\mathrm{a}} \\
\text { Impaired glucose tolerance: normal fasting glucose }<6.1 \mathrm{mmol} / \mathrm{L}^{\mathrm{a}} \text { and } \\
\text { 2-h postoral glucose tolerance test glucose } 7.8 \text { to } 11.0 \mathrm{mmol} / \mathrm{L}^{\mathrm{a}} \\
\text { Prediabetes: Impaired fasting glucose and/or impaired glucose } \\
\text { tolerance and/or glycated hemoglobin between } 6.0 \% \text { and } 6.4 \% \\
\text { Type } 2 \text { diabetes: fasting glucose } \geq 7.0 \mathrm{mmol} / \mathrm{L}^{\mathrm{a}} \text { and/or } 2 \text {-h postoral } \\
\text { glucose tolerance test glucose } \geq 11.1 \mathrm{mmol} / \mathrm{L}^{\mathrm{a}} \text { and/or glycated } \\
\text { hemoglobin } \geq 6.5 \%\end{array}$ \\
\hline $\begin{array}{l}\text { Bao and } \\
\text { colleagues, } 21,22 \\
2016\end{array}$ & $\begin{array}{l}\text { Validated semi-quantitative } \\
\text { food frequency } \\
\text { questionnaire. }\end{array}$ & $\begin{array}{l}\text { Type } 2 \text { diabetes diagnosis was self-reported. A validation study } \\
\text { showed } 94 \% \text { of self-reported cases were confirmed by medical } \\
\text { records }\end{array}$ \\
\hline $\begin{array}{l}\text { Tobias and } \\
\text { colleagues, } \\
2012 \text { and } 2018\end{array}$ & $\begin{array}{l}\text { Administered as part of survey } \\
\text { questionnaire }\end{array}$ & $\begin{array}{l}\text { Diagnostic criteria: American Diabetes Association Guidelines } 1997 \\
\text { Type } 2 \text { diabetes: } 1 \text { ) One or more classic symptoms (eg, excessive thirst, } \\
\text { polyuria, unintentional weight loss, or hunger) plus elevated glucose } \\
\text { concentrations (fasting plasma glucose } \geq 7.0 \mathrm{mmol} / \mathrm{L}^{\mathrm{a}} \text { or random } \\
\text { plasma glucose } \geq 11.1 \mathrm{mmol} / \mathrm{L}^{\mathrm{a}} \text { ); } 2 \text { ) No symptoms reported but } \geq 2 \\
\text { elevated plasma glucose concentrations on more than } 1 \text { occasion } \\
\text { (fasting glucose } \geq 7.0 \mathrm{mmol} / \mathrm{L}^{\mathrm{a}} \text {; random glucose } \geq 11.1 \mathrm{mmol} / \mathrm{L}^{\mathrm{a}} \text {, or } \\
\text { 2- postoral glucose tolerance test glucose } \geq 11.1 \mathrm{mmol} / \mathrm{L}^{\mathrm{a}} \text { ); or } 3 \text { ) } \\
\text { Treatment with insulin or an oral hypoglycemic agent. Before } 1998 \text {, } \\
\text { fasting plasma glucose } \geq 7.8 \mathrm{mmol} / \mathrm{L}^{\mathrm{a}} \text { was used instead of } \geq 7.0 \\
\text { mmol/L } \mathrm{L}^{\mathrm{a}} \text { according to the criteria of the National Diabetes Data } \\
\text { Group }\end{array}$ \\
\hline $\begin{array}{l}\text { Andersson-Hall } \\
\text { and } \\
\text { colleagues, }^{30} \\
2018\end{array}$ & $\begin{array}{l}\text { Validated semiquantitative food } \\
\text { frequency questionnaire. } \\
\text { Completed during study visit }\end{array}$ & $\begin{array}{l}\text { Blood samples were taken at the study visit } 6 \text { y after pregnancy. } \\
\text { Diagnostic criteria: } 1999 \text { World Health Organization guidelines } \\
\text { Type } 2 \text { diabetes: fasting glucose } \geq 7.0 \mathrm{mmol} / \mathrm{L}^{\mathrm{a}} \text { or } 2 \text {-h postoral glucose } \\
\text { tolerance test glucose } \geq 11.1 \mathrm{mmol} / \mathrm{L}^{\mathrm{a}} \\
\text { Impaired glucose tolerance: fasting glucose } 6.1 \text { to } 6.9 \mathrm{mmol} / \mathrm{L}^{\mathrm{a}} \text { and/or } \\
\text { 2-h postoral glucose tolerance test glucose } 7.8 \text { to } 11.0 \mathrm{mmol} / \mathrm{L}^{\mathrm{a}}\end{array}$ \\
\hline $\begin{array}{l}\text { Kim and } \\
\text { colleagues, } \\
2011\end{array}$ & $\begin{array}{l}\text { 24-h Recall } \\
\text { Administered by a skilled } \\
\text { dietitian }\end{array}$ & $\begin{array}{l}\text { Type } 2 \text { diabetes and prediabetes were assessed at a clinical visit at 6- } \\
12 \text { wk postpartum } \\
\text { Diagnostic criteria: American Diabetes Association Guidelines } 1997 \\
\text { Type } 2 \text { diabetes: fasting glucose }>7.0 \mathrm{mmol} / \mathrm{L}^{a} \text { or } 2-\mathrm{h} \text { glucose }>11.1 \\
\mathrm{mmol} / \mathrm{L}^{\mathrm{a}} \\
\text { Impaired glucose tolerance: fasting glucose }<6.1 \mathrm{mmol} / \mathrm{L}^{\mathrm{a}} \text { and } 2-\mathrm{h} \\
\text { glucose } 7.8 \text { to } 11.0 \mathrm{mmol} / \mathrm{L}^{a} \\
\text { Impaired fasting glucose: fasting glucose } 6.1 \text { to } 6.9 \mathrm{mmol} / \mathrm{L}^{\mathrm{a}} \text { inclusive } \\
\text { with } 2 \text { - } \mathrm{h} \text { glucose }<7.8 \mathrm{mmol} / \mathrm{L}^{\mathrm{a}}\end{array}$ \\
\hline
\end{tabular}

${ }^{\mathrm{a}}$ To convert $\mathrm{mmol} / \mathrm{L}$ glucose to $\mathrm{mg} / \mathrm{dL}$, multiply $\mathrm{mmol} / \mathrm{L}$ by 18.02 . To convert $\mathrm{mg} / \mathrm{dL}$ glucose to $\mathrm{mmol} / \mathrm{L}$, multiply $\mathrm{mg} / \mathrm{dL}$ by 0.0555 . Glucose of $6.1 \mathrm{mmo} / \mathrm{L}=109.92 \mathrm{mg} / \mathrm{dL}$. 
Table 7. Quality assessment for each individual observational study included in a systematic review on associations of dietary intake with diabetes outcomes in women with a history of gestational diabetes ${ }^{\mathrm{a}}$

\begin{tabular}{|c|c|c|c|c|c|c|c|c|c|}
\hline \multirow[b]{2}{*}{ Study } & \multicolumn{4}{|c|}{ Selection } & \multirow[b]{2}{*}{$\begin{array}{l}\text { Comparability } \\
\text { Comparability } \\
\text { of cases and } \\
\text { controls on } \\
\text { basis of design } \\
\text { or analysis }\end{array}$} & \multicolumn{3}{|c|}{ Outcome } & \multirow[b]{2}{*}{$\begin{array}{l}\text { Total } \\
\text { score }\end{array}$} \\
\hline & $\begin{array}{l}\text { Representativeness } \\
\text { of exposed cohort }^{\text {b }}\end{array}$ & $\begin{array}{l}\text { Selection of } \\
\text { nonexposed } \\
\text { cohort }^{c}\end{array}$ & $\begin{array}{l}\text { Ascertainment } \\
\text { of exposure }^{d}\end{array}$ & $\begin{array}{l}\text { Outcome } \\
\text { not present } \\
\text { at start of } \\
\text { study }\end{array}$ & & $\begin{array}{l}\text { Outcome } \\
\text { assessment }^{9}\end{array}$ & $\begin{array}{l}\text { Adequate } \\
\text { duration of } \\
\text { follow-up }\end{array}$ & $\begin{array}{l}\text { Adequacy of } \\
\text { follow-up rate }\end{array}$ & \\
\hline $\begin{array}{l}\text { Tobias and colleagues, }{ }^{24} \\
2018\end{array}$ & C & $A \star$ & $B \star$ & $A \star$ & $A \star B \star$ & $B \star$ & $A \star$ & D & 7 \\
\hline $\begin{array}{l}\text { Andersson-Hall and } \\
{\text { colleagues, }{ }^{30}}^{2018}\end{array}$ & $B \star$ & $A \star$ & $B \star$ & B & $A \star$ & $A \star$ & $A \star$ & $B \star$ & 7 \\
\hline $\begin{array}{l}\text { Bao and colleagues, } \\
2016\end{array}$ & C & $A \star$ & $B \star$ & $A \star$ & $A \star B \star$ & $B \star$ & $A \star$ & D & 7 \\
\hline $\begin{array}{l}\text { Bao and colleagues, } \\
2016\end{array}$ & C & $A \star$ & $B \star$ & $A \star$ & $A \star B \star$ & $B \star$ & $A \star$ & D & 7 \\
\hline
\end{tabular}

Risk of bias was assessed using the Newcastle-Ottawa Scale. A study can be awarded a maximum of one star for each numbered item within the Selection and Outcome categories. A maximum of two stars can be given for Comparability. ${ }^{b}$ Representativeness of the exposed cohort was scored as (A [star]) truly representative of the average postpartum or mid-age woman with a history of gestational diabetes in the community (random sample); (B [star]) somewhat representative of the average postpartum or mid-age woman with a history of gestational diabetes in the community; (C) selected group of users (eg, only specific occupation); (D) no description of the derivation of the cohort.

'Selection of the nonexposed cohort was scored as (A [star]) drawn from the same community as the exposed cohort; (B) drawn from a different source; (C) no description of the derivation of the nonexposed cohort.

${ }^{\mathrm{d} A s c e r t a i n m e n t ~ o f ~ e x p o s u r e ~ w a s ~ s c o r e d ~ a s ~(A ~[s t a r]) ~ s e c u r e ~ r e c o r d ~(e g, ~ c o n t r o l l e d ~ d i e t) ; ~(B ~[s t a r]) ~ s t r u c t u r e d ~ i n t e r v i e w / v a l i d a t e d ~ d i e t a r y ~ r e c a l l / d i e t ~ h i s t o r y / f o o d ~ f r e q u e n c y ~ q u e s t i o n n a i r e ; ~(C) ~ w r i t t e n ~ s e l f-r e p o r t ~(e g, ~ n o n v a l i d a t e d ~ d i e t a r y ~ a s s e s s m e n t) ; ~(D) ~ n o ~}$ description.

eDemonstration that outcome of interest was not present at start of study was scored as (A [star]) yes (no type 1 or type 2 diabetes before pregnancy and before study entry); (B) no.

${ }^{\mathrm{f}}$ Comparability of cohorts on the basis of the design or analysis was scored as (A [star]) study controls for age, ethnicity and body mass index; (B [star]) study controls for any additional factor (eg, parity, family history of diabetes, smoking, physical activity, other dietary factors).

${ }^{9}$ Outcome assessment was scored as (A [star]) independent blind assessment (eg, hospital record/oral glucose tolerance test); (B [star]) record linkage or validated self-reported diagnosis; (C) self-report (not validated); (D) no description.

Adequate duration of follow-up for outcomes to occur was scored as (A [star]) yes, in the case that—after baseline-all women were screened for type 2 diabetes or answered a question on whether they were diagnosed or treated for type 2 diabetes; (B) no.

'Adequacy of follow-up rate was scored as (A [star]) complete follow-up or all subjects accounted for using multiple imputation; (B [star]) subjects lost to follow-up unlikely to introduce bias (samples are comparable based on comparison of included and excluded participants) or $\leq 10 \%$ lost during follow-up; (C) follow-up rate < $90 \%$ or no description of those lost; (D) no statement. 


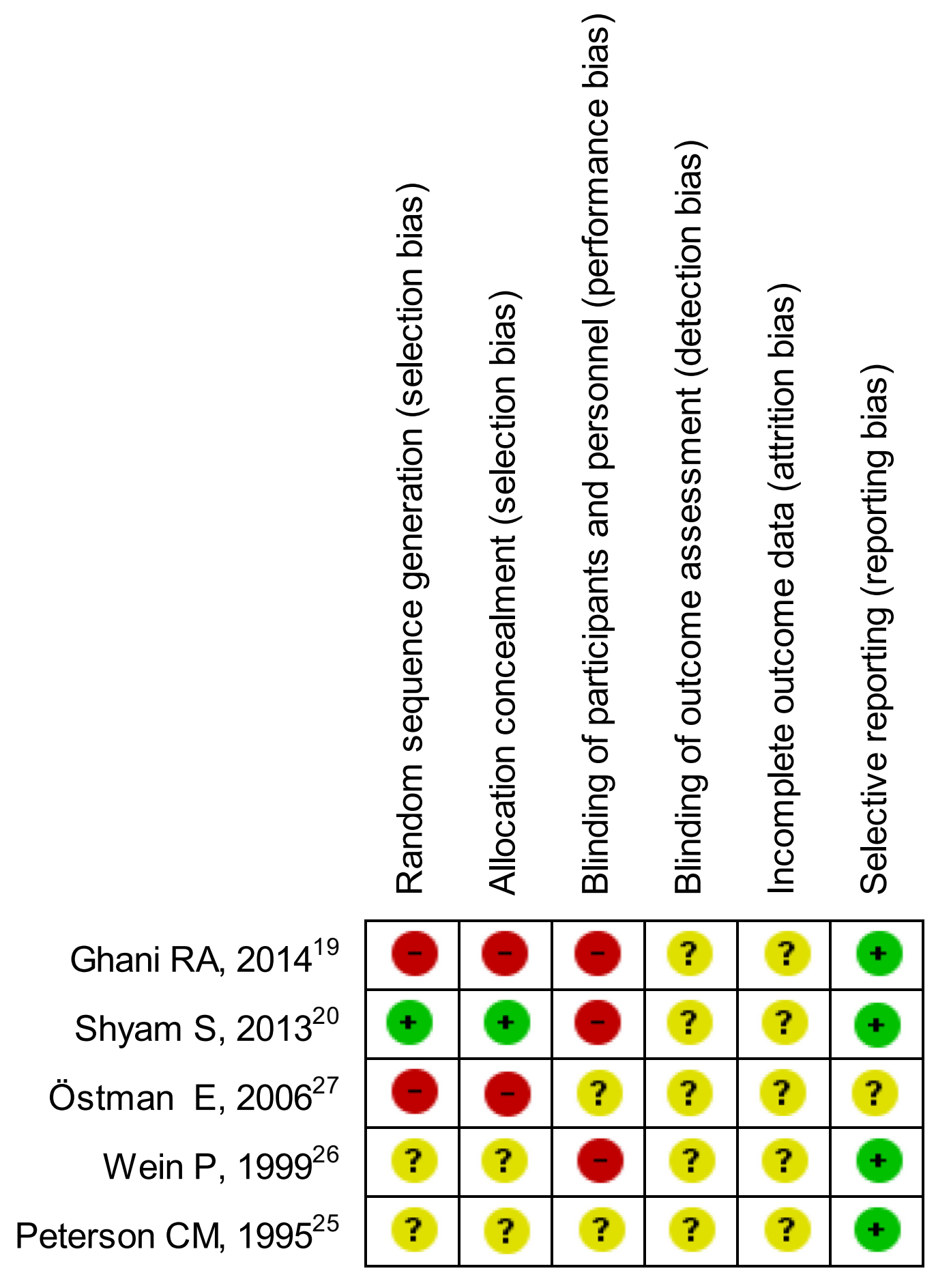

\section{† Low risk ? Unclear risk - High risk}

Figure 4. Risk of bias for each individual intervention study included in a systematic review on effects of dietary interventions on diabetes outcomes in women with a history of gestational diabetes. Risk of bias was assessed using the Cochrane risk of bias tool. ${ }^{16}$ 
Random sequence generation (selection bias)

Allocation concealment (selection bias)

Blinding of participants and personnel (performance bias)

Blinding of outcome assessment (detection bias)

Incomplete outcome data (attrition bias)

Selective reporting (reporting bias)
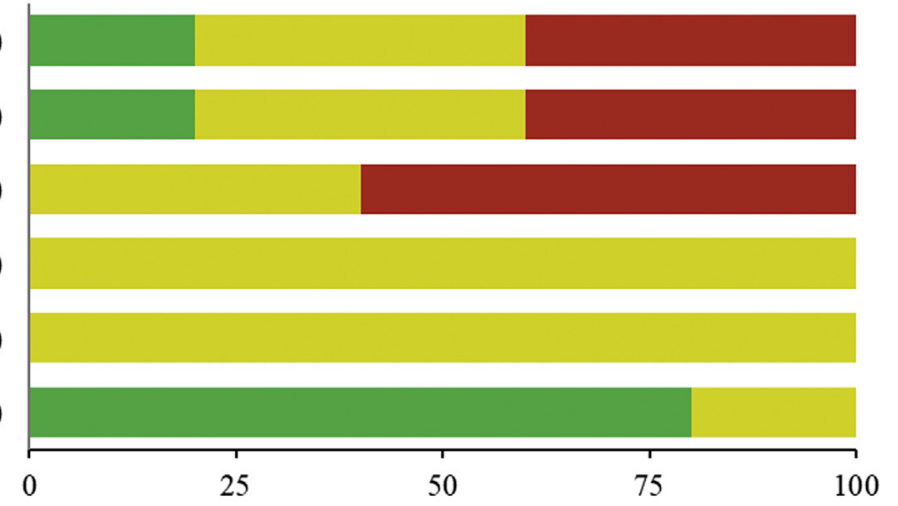

\section{- Low risk of bias}

Unclear risk of bias

- High risk of bias

Figure 5. Risk of bias summary for five intervention studies included in a systematic review on effects of dietary interventions on diabetes outcomes in women with a history of gestational diabetes. Risk of bias was assessed using the Cochrane risk of bias tool. ${ }^{16}$ 